Article

\title{
Inspection Data Collection Tool for Field Testing of Photovoltaic Modules in the Atacama Desert
}

\author{
Pía Vásquez ${ }^{1}$, Ignacia Devoto ${ }^{1}$, Pablo Ferrada ${ }^{2, *(\mathbb{D}}$, Abel Taquichiri ${ }^{2}$, Carlos Portillo ${ }^{2} \mathbb{D}$ \\ and Rodrigo Palma-Behnke 1,3
}

1 Centro de Energía, DIE, FCFM, Universidad de Chile, Av. Tupper 2007 (4th Floor), Santiago 8370451, Chile; pia-javiera.vasquezivera@cea.fr (P.V.); ignacia.devoto@isc-konstanz.de (I.D.); rodpalma@cec.uchile.cl (R.P.-B.)

2 Centro de Desarrollo en Energías Antofagasta, Universidad de Antofagasta, Av. Universidad de Antofagasta \#02800, Antofagasta 1271155, Chile; abel.taquichiri.ayaviri@ua.cl (A.T.); carlos.portillo@uantof.cl (C.P.)

3 Department of Electrical Engineering, University of Chile, Av. Tupper 2007, Santiago 8370451, Chile

* Correspondence: pablo.ferrada@uantof.cl; Tel.: +56-55-2-513530

Citation: Vásquez, P.; Devoto, I.; Ferrada, P.; Taquichiri, A.; Portillo, C.; Palma-Behnke, R. Inspection Data Collection Tool for Field Testing of Photovoltaic Modules in the Atacama Desert. Energies 2021, 14, 2409.

https://doi.org/10.3390/en14092409

Academic Editor:

Senthilarasu Sundaram

Received: 26 March 2021

Accepted: 20 April 2021

Published: 23 April 2021

Publisher's Note: MDPI stays neutral with regard to jurisdictional claims in published maps and institutional affiliations.

Copyright: (c) 2021 by the authors. Licensee MDPI, Basel, Switzerland. This article is an open access article distributed under the terms and conditions of the Creative Commons Attribution (CC BY) license (https:// creativecommons.org/licenses/by/ $4.0 /)$.

\begin{abstract}
The Atacama Desert receives the highest levels of solar irradiance in the world with an annual average of $2500 \mathrm{kWh} / \mathrm{m}^{2}$ for the global horizontal irradiance and $3500 \mathrm{kWh} / \mathrm{m}^{2}$ for the direct normal irradiance. One of the challenges is the large portion of ultraviolet light. This part of the spectrum be detrimental for the encapsulant materials, reducing their lifetime. To develop a module adapted to the Atacama Desert conditions, it is imperative to have standardized information from first-hand about the typical faults experienced by photovoltaic modules operating in the desert. This work reports on the design and implementation of the Inspection Data Collection Tool to evaluate crystalline silicon-based moules operating in desert climates. The tool brings together novel features of compatibility with current standards, efficient mobile-type instrumentation (equipment and tools), clear procedures/protocols for non-expert users and low development costs. A total of 95 modules were inspected to characterize failure/degradation issues. Three components of the solar modules were assessed: front cover glass, ethylene-vinyl acetate encapsulant and solar cells. Seven abnormalities were analyzed: Soiling, front cover glass discoloration, encapsulant delamination, hotspots, partial shading, cell fracture and faulty soldering. Soiling was the most common issue, showing correlation between dust deposition and location.
\end{abstract}

Keywords: crystalline silicon; fielded PV modules; Atacama Desert; degradation

\section{Introduction}

The Atacama Desert, within its $105,000 \mathrm{~km}^{2}$ receives the highest levels of solar irradiance in the world with an annual average of $2500 \mathrm{kWh} / \mathrm{m}^{2}$ for the global horizontal irradiance $(\mathrm{GHI}), 3500 \mathrm{kWh} / \mathrm{m}^{2}$ for the direct normal irradiance (DNI) and $4000 \mathrm{~h}$ of sunlight. The Atacama Desert not only presents advantages but also important challenges due to the high ultraviolet (UV) irradiance. According to [1] the dose in the Atacama Desert in the UV-B range is nearly $40 \%$ higher than that in the north of Africa. This, in combination with an annual average of $2 \mathrm{~mm}$ of rainfall (in the key zones of the desert) and an average temperature of more than $30^{\circ} \mathrm{C}$ in the summer, may lead to a fast degradation of the encapsulant materials of photovoltaic (PV) modules operating in the desert. the main root cause for PV module's degradation is the interaction between materials within the PV module [2]. The encapsulant materials not only allow to have a solid structure to transport, manipulate and install the PV module but also maintain a safe electrical insulation of the device and protect its active layers against the environmental conditions. Therefore, the degradation of the encapsulant materials not only leads to the emanation of faults and subsequent degradation modes within the solar panel but also can lead to serious safety problems. 
Currently, in Chile, PV modules are mostly imported from and certified in China, Europe or USA. Those modules are usually designed to operate in weather conditions that are normal/typical for those places. Likewise, international certification ensures that their products meet established quality and performance standards under most severe climatic conditions. Nevertheless, the climate conditions, severe or normal, in the Atacama Desert are not the same as North America or Europe. In conclusion, the special conditions such as extreme aridity and UV radiation in the Atacama Desert open new challenges and opportunities for the development of innovative energy solutions. Today, the development of a solar power industry is on the way, and a glass/glass (bifacial) PV module specially designed for this desert is one of the most important targets for PV R\&D\&I within the national solar program. Despite this development is particular to the Atacama Desert, this kind of initiatives are carried out elsewhere for specific climates such as other deserts or tropical, subtropical climates [3,4]. In addition, residential and/or small PV applications such as for rural context are also associated to specific conditions which may differ to those found in a desert such as Atacama.

To succeed in the development of a module adapted to the Atacama Desert conditions (bifacial PV module specially design for Atacama Desert conditions), it is imperative to have first-hand information about the typical faults experienced by PV modules that have been operating for several years in various areas within the Atacama Desert. Moreover, it is important that this information is reliable and standardized. The total installed capacity in Chile to February 2021 reached 3.4 GWp [5]. However, PV modules of small applications in the rural context have a previous existence, before large PV projects were conceived. Therefore, studying these older modules can provide relevant information. Failures and degradation mechanisms of these and any photovoltaic (PV) modules depend on module materials, construction, and the climate where they operate [6]. The available data of typical/dominant failures for c-Si PV modules in Atacama Desert, Chile, is scarce or nonexistent [7]. Most common failure modes for PV modules operating in desert or hot-dry climate conditions are briefly reviewed in the following.

Kuitche, Pan and TamizhMani [8] investigated dominant failure modes for fielded crystalline silicon (c-Si) PV modules under desert climate in Arizona, USA. They used the Failure Mode and Effects (Criticallity) Analysis (FMEA/FMECA) technique for this purpose. They determined that solder bond failures and encapsulant discoloration are the dominant modes under the hot and dry climate of Arizona. Berman, Biryukov and Faiman [9] evaluated a grid-connected PV system in Negev Desert, Israel. They observed browning EVA after 5 years of operation. Shrestha et al. [10] evaluated $5900 \mathrm{c}-\mathrm{Si}$ glass/polymer modules fielded for 6 to 16 years in three different PV power plants under hot and dry desert climate in Arizona, USA. They concluded that the dominant failure was solder bond fatigue with/without gridline contact fatigue. Yedidi [11] evaluated two 16-year-old PV plants to ascertain degradation rates and various failure modes in hot and dry climate. He suggested that the primary degradation mode was encapsulant browning leading to thermo-mechanical solder bond fatigue (cell/ribbon and ribbon/ribbon). Mallineni [12] evaluated two PV power plants, one in Glendale and the other in Mesa, both from Arizona. Modules operated for 12 years under hot and dry climate conditions. She concluded that the major cause of degradation of modules from Glendale's power plant was high series resistance (probably due to solder/bond thermo-mechanical fatigue) and the failure mode ribbon/ribbon solder bond fatigue. Suleske [13] investigated 1900 aged (10-17 years) grid-tied PV modules installed in the desert climatic condition of Arizona. He documented visual defects, infrared images and IV curve measurements. He concluded that the browning of encapsulant was the largest issue followed by hotspots. Singh, Belmont and TamizhMani [14] analyzed the degradation of 1900 fielded PV modules operating for 12 to 18 years under hot and dry climate conditions. They wanted to identify potential induced degradation (PID) failure. For this purpose, all series strings at the power plant were positively biased with respect to the ground potential (negative). They indicate that modules do not appear to experience PID effect, and they attribute this behavior 
to the dry climate of Arizona. According to the reviewed literature, dominant failure modes for c-Si PV modules operating in desert or hot-dry climate conditions are the solder bond (cell/ribbon), solder bond (ribbon/ribbon), encapsulant discoloration (browning or yellowing) and hot spots.

Based on the guidelines provided by organizations such as the International Electrotechnical Comission (IEC), the American Society for Testing and Materials, the National Renewable Energy Laboratory of the United States, visual inspection (IEC 61215-1 [15], ASTM E1799 [16], IEC PAS 62257-10 [17], NREL [18]), IV curve measurements (IEC 609041 [19], ASTM E1036 [20]), thermal imaging (IEC TS 62446-3 [21], IEA PVPS for IR and electroluminescence [22] are common and required methods for the characterization of PV modules operating in outdoor conditions. Packard, Wohlgemuth and Kurtz [18] developed a tool for the evaluation of visually observable defects in fielded PV modules. The IEC is currently developing a new standard, IEC 62257-10 (ed. 2017), that for now is a Publicly Available Specification or a published draft. IEC PAS 62257-10 [17] is designed to be used as a guide to visually inspect front-contact mc-Si and c-Si solar PV modules for major defects. This standard presents its own checklist for major failures (specifying one checklist for new modules and other for used modules), but the components are inspected following the procedure developed by Packard et al. [18].

The aim of this work is to design and implement an IDCTool to evaluate PV modules operating in desert climates and to characterize samples. The design is based on international standards and norms for PV modules installed in a rural context, while employing cost-effective tools, for a non-expert user to carry out the tasks defined in the protocol. This procedure is exportable and applicable to other contexts. Thus, the relevance of such a tool is the possibility to provide continuous learning regarding specific local contexts leading to key information for the development of PV modules, implementation, maintenance, and operation practices. Using the tool allows the posterior elaboration of recommendations through the analysis of the collected data. For recommendations, it is important to have reliable and consistent conclusions about the information under analysis. Therefore, the IDCTool is designed to deliver a basic/minimum set of information. Furthermore, the collected information can be analyzed via typical patterns of visual or thermal abnormalities, which are explained with images examples. Likewise, current-voltage (IV) characteristic can be studied from a qualitative (shape of the curve) or quantitative (electrical parameter values) point of view.

\section{Materials and Methods}

\subsection{Location}

The IDCTool was used to perform a field test campaign in the north part of the Atacama Desert in Chile (the XV Arica and Parinacota Region). This region is characterized by three different landscapes: valleys, desert, and plateau (or highlands). The region has a total surface of $16,898.3 \mathrm{~km}^{2}$. The complete Arica and Parinacota region is shown in Figure $1 \mathrm{a}-\mathrm{c}$. The commune of Arica is closer to the coast while the commune of Camarones is in the middle of the intermediate depression and the communes of Parinacota (Putre and General Lagos) are closer to the mountains.

Due to the latitude, between the Ecuador and the Tropic of Capricorn, the southwest winds predominate in the region. The high pressure of the Pacific Ocean Anticyclone triggers the descent of warm air from the Ecuador, which enables permanent good weather and absence of precipitation in the littoral and intermediate depression. Although the precipitations in the littoral do not surpass the millimeter, concentrating only in winter, the tropical influence (masses of humid air) accumulate annually $300 \mathrm{~mm}$ in the highland region. The phenomenon known as Camanchaca (superficial fog), which occurs in the coastal zone, is caused by the cooling of the superficial warm air (less than 1000 m.a.s.l.) that goes through the cold current of Humboldt. The progress of this fog is stopped by the coastal walls. Due to the altitude of the region (up to 6000 m.a.s.l. within the volcanoes), the temperature of the coastal zone $\left(18^{\circ} \mathrm{C}\right)$ decreases towards the mountain zone $\left(11^{\circ} \mathrm{C}\right)$. 
The average monthly temperatures of the region can reach $-10{ }^{\circ} \mathrm{C}$ and increase up to $26{ }^{\circ} \mathrm{C}$. Due to the effects of El Niño phenomenon, the marine waters increment their temperature that in turn increase the temperature of the coastal air in $1^{\circ} \mathrm{C}$ or $2^{\circ} \mathrm{C}$. La Niña phenomenon leads to the opposite effect in the coastal air temperature.

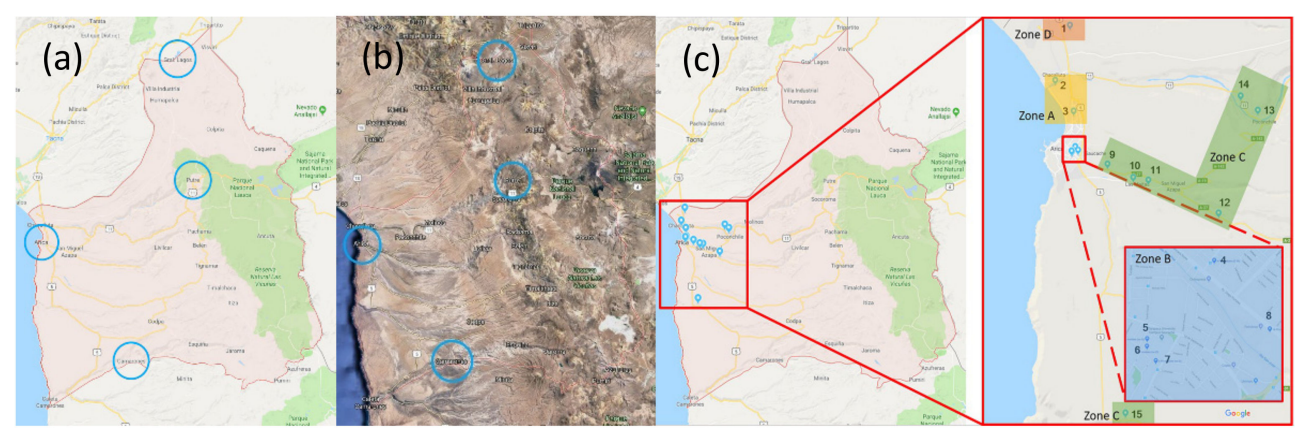

Figure 1. (a) Left: Google map of Arica and Parinacota Region. The four communes are shown inside a blue circle. (b) Right: Satellite Google map of Arica and Parinacota Region. Communes are highlighted again. (c) Mapping of the inspected sites within Arica's campaign.

According to the Köppen Classification [23], this region presents four types of climates: Dry Arid with Abundant Cloudiness Climate (BWn), Normal Dry Arid Climate (BW), Hot Dry Arid Climate (BWh) and Hot Semi-Arid Climate (BSh). In the order presented before, the four climates extend from the coastal to the highlands. Climates of type B are arid, which are mainly controlled by the dryness, not the temperature. The aridity not only indicates a deficit of precipitations, but also the loss of water within the soil.

Figure $1 \mathrm{c}$ shows the 15 sites that were visited for the campaign. The locations are separated into 4 zones:

- Zone A: coastal region (locations 2 and 3).

- Zone B: city center region (locations 4, 5, 6, 7 and 8).

- Zone C: valley region (locations 9, 10, 11, 12, 13, 14 and 15).

- Zone D: desert region (location 1).

According to the classification listed above, similar locations are classified together. Here, due to the number of locations visited, the coastal and desert regions are the ones with less information. In contrast, the city and valley regions contain several locations.

\subsection{Materials}

Within the 15 locations, $95 \mathrm{PV}$ modules were inspected. The inspected modules were from 9 different manufacturers. Specifically, for SUNEL manufacturer, two different models were found (SNMM200(72) and SNM-P250(60)).

Table A1 in the Appendix A shows a summary of the most important electrical parameters of the different PV modules found within the 15 locations. The information was obtained from the datasheets from the manufacturers. Series resistance values in Table A1 were obtained from the database within the software SolarCert Elements from the Seaward company. This information is needed to translate measured IV curves into curves at standard testing conditions (STC).

The 15 locations distributed within the four zones described above contain different number of installed PV modules from different manufacturers. Furthermore, each location has its own estimated deployment date. The last means that PV modules installed in different locations are exposed to different temporal intervals. Also, more than one system with different installation dates can be found in the same location. The differences among the four zones, hence locations, are described in Table A2 (Appendix A).

From Table A2 (Appendix A), zone A contains two locations with installed PV modules from SOLAR WORLD and ET TOWARDS EXCELLENCE. Each location has 6 PV modules, where location 2 is operating since 2013 and location 3 is operation since 2015. It is 
important to highlight that some locations have more than one system, where each system can have different PV modules and/or different estimated deployment date. The last happens within locations 7 (zone B), 14 (zone C) and 1 (zone D). Location 7 contains two different systems, one with PV modules from LUXOR and the other from JA SOLAR. The first one was installed in 2011 while the second one was installed in 2015. It must be highlighted that the only location using PV modules from two different manufacturers in the same system was location 1 in zone $\mathrm{D}$.

\subsection{Instrumentation}

The thermal camera FLIR ONE pro was used. According to the minimum requirements of thermal cameras for PV application in IEC 62446-3 [21], the thermal spectral range of FLIR ONE pro is within the desired values (e.g., the spectral range of 8-14 $\mu \mathrm{m}$ ). Likewise, the thermal sensitivity is another important parameter that the FLIR ONE pro fulfills $\left(150 \mathrm{mK} \leq 0.1 \mathrm{~K}\right.$ at $30^{\circ} \mathrm{C}$, which means that the temperature resolution is as low as $150 \mathrm{mK}$ up to $0.1 \mathrm{~K}$ at $30^{\circ} \mathrm{C}$ ). Regarding the object temperature range, FLIR ONE pro fulfills the requirements exceeding the upper limit by $280{ }^{\circ} \mathrm{C}$. In contrast, a few requirements are not in the desired range. According to the minimum requirements on the IEC, the accuracy (or absolute error measurements) should be less than $2 \mathrm{~K}$, but FLIR ONE pro is $\pm 3 \mathrm{~K}$. The emissivity can be adjustable in four values and the reflected temperature is fixed at $22{ }^{\circ} \mathrm{C}$. Regarding the recommendation of $3 \mathrm{~cm}$ of the module edge per pixel as maximum, which can be translated to $5 \times 5$ pixels per solar cell or a maximum IFOV of $30-32 \mathrm{~mm}$, the FLIR ONE pro fulfills the requirement with a pixel size of $12 \mu \mathrm{m}$. According to IEA PVPS [22], the thermal resolution of FLIR ONE pro is within the low class. This thermal resolution is typical for low-cost cameras and is within a reasonable resolution. Furthermore, IEA PVPS recommends that the visual resolution shall be higher than the thermal resolution for better details. FLIR ONE pro fulfills this requirement with a second lens with a resolution of $1440 \times 1080$ that is higher than its thermal resolution.

The characteristic curves of the modules were measured using the I-V tracer PV200 from Seaward. The operation of the I-V tracer together with the Solar Survey 200R irradiance meter allows converting the measurements to STC, using either the PVMobile app (smartphone) or SolarCert Elements software (PC). The display shows the open circuit voltage, short circuit current, maximum power point voltage, current and power, as well as the fill factor of the measured modules. The I-V tracer performs the measurements required by the IEC 62,446 and according to IEC 61,829 [24]; whereby the accuracy for voltage, current and power is $\pm 0.5 \%, 1 \%$ and $2 \%$, respectively.

The Solar Survey 200R irradiance meter, as part of the PV210 kit, contains a reference cell above the display. The metallic thermocouple is for ambient temperature measurements while the white rubber is for temperature measurements of the PV module. Since the tracer in conjunction with the irradiance meter compute the corrections for STC (Standards IEC 60904-1 [19] and ASTM E1036 [20]), a third temperature sensor for the reference cell within the irradiance meter is not required. Additionally, the PB210 kit also brings a DC clamp meter to measure the current (AC or DC) in real time.

An iPad was used to fill the visual inspection survey and to take thermal picture in combination with FLIR ONE pro. Figure 2 illustrates the minimum equipment required. 


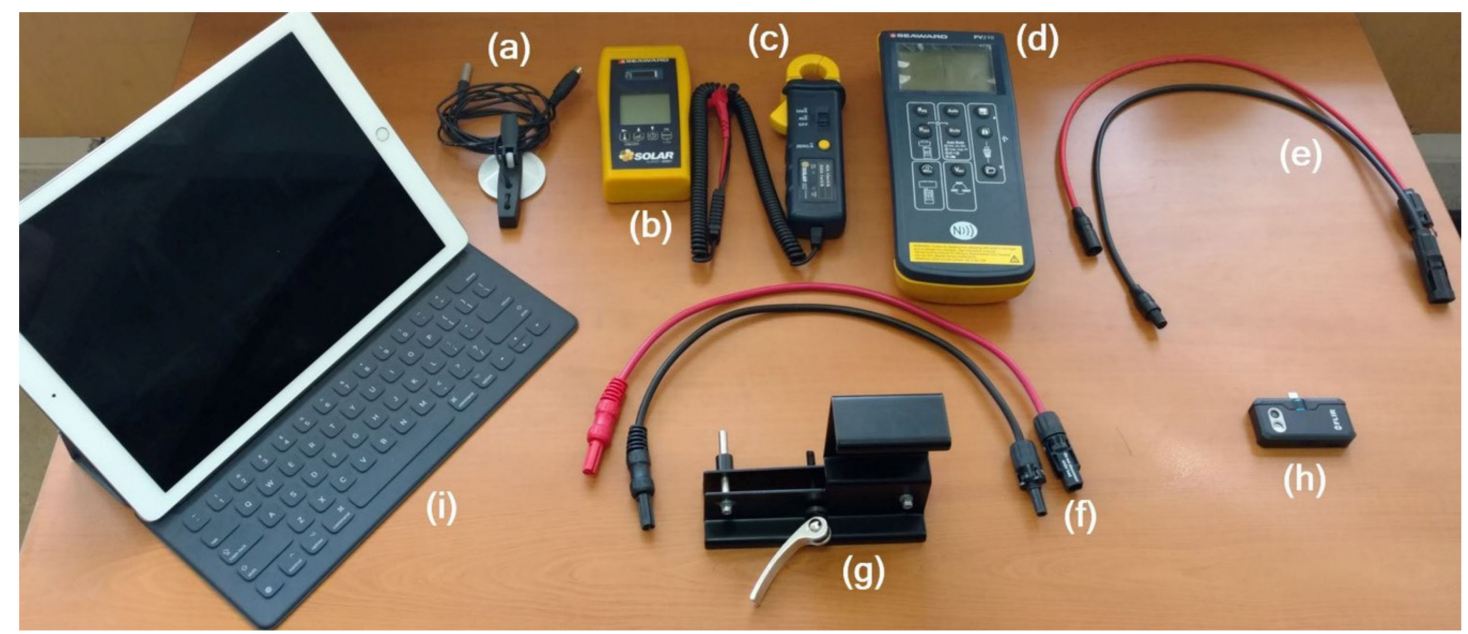

Figure 2. Minimum equipment and tools for data collection in the field. (a) Temperature sensors. (b) Irradiance sensors. (c) Direct current (DC clamp) ampere-meter. (d) Current-Voltage (IV) tracer. (e) MC3 to MC4 adapter leads. (f) MC4 tests leads. (g) Irradiance meter mounting bracket. (h) FLIR ONE pro camera. (i) iPad.

\subsection{Methodology}

\subsubsection{Inspection Data Collection Tool}

The general framework used for the design of the proposed IDCTool is showed in Figure 3. To come up to the tool, the process consisted of 4 stages. First, theoretical background, state of the art and previous experiences were revised. Second, clear definitions of the scope of the tool needed to be defined. Third, the practical work was carried out. Four, symptomatic issues to the PV modules tested were analyses and possible explanations were drawn.

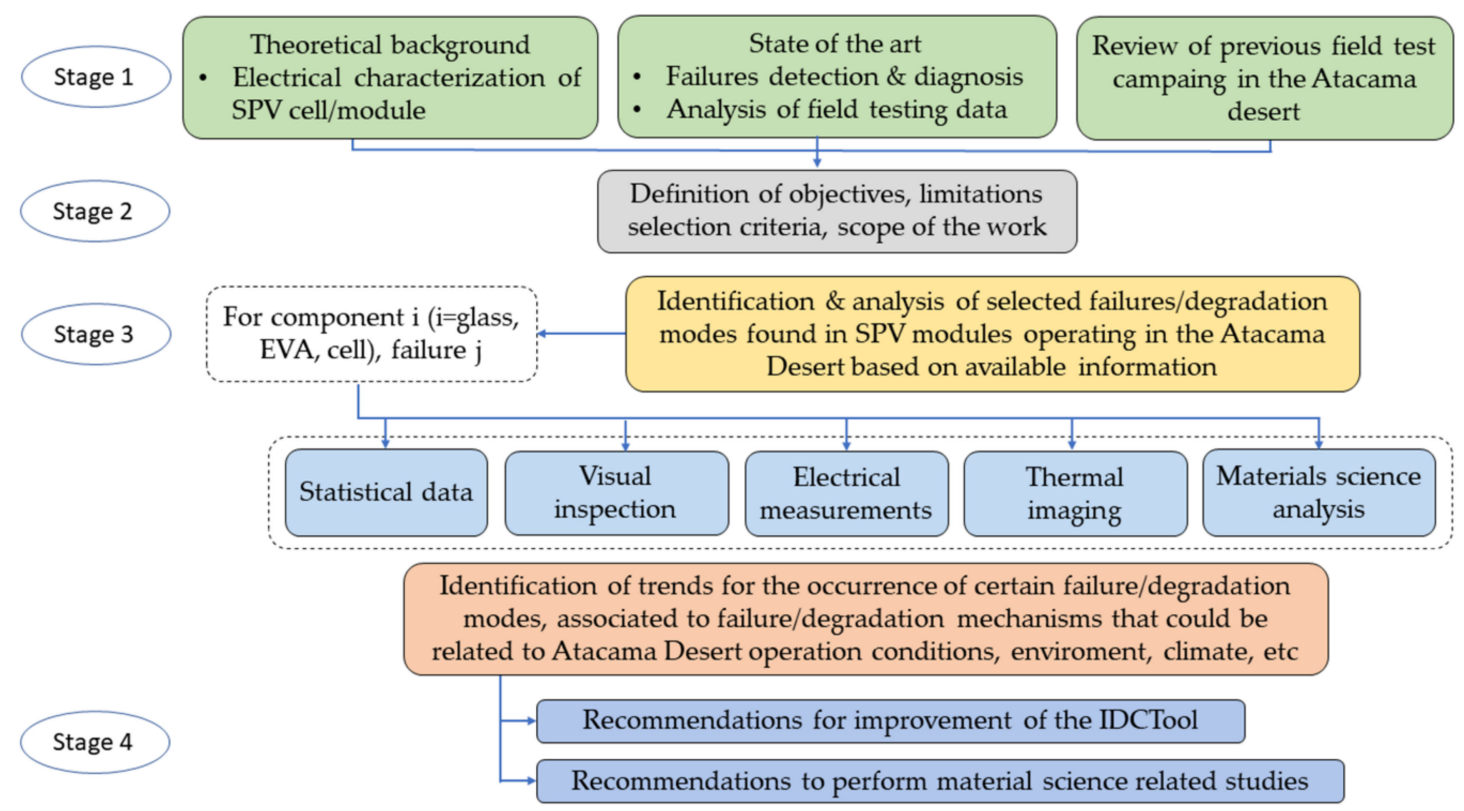

Figure 3. Methodological strategy for the elaboration of the tool.

The IDCTool was developed for (mono or multi) c-Si technology, operating in desert conditions. The aim of this tool is to create a database with information regarding the most typical failures or abnormalities that PV modules develop while they operate in the Atacama Desert. It is not intended to obtain a full examination to scan all the issues that a single PV module may experience. A full scan will generate a huge amount of information that ultimately may not be required or will make the analysis of the data more complex. 
Furthermore, it is imperative to maintain a low (but sufficient) amount of details to examine a single PV module in a few minutes. The time is important because this tool is designed to make a scan of all (within the reasonable constraints) the PV modules operating in the Atacama Desert until today.

The IDCTool is the combination of the form of field testing (survey), the equipment and tools, and the procedures to acquire data in the field. Appendix B shows the survey. Regarding the equipment and tools, the minimum equipment necessary to proceed with the inspection is: iPad or tablet to fill the survey, an IV tracer with its components (DC clamp) ampere-meter and sensors for temperature and irradiance) and the thermal camera. In relation to the procedure, in general, the inspection starts with a checklist of the equipment and tools with their right configuration, followed by the filling of the survey for visual inspection and ending with the acquirement of electronic records. The electronic records start with the thermal inspection due to the necessity of thermal equilibrium (thermal steady state condition) followed by the IV curve measurements.

The survey is mainly based on the visual inspection data collection tool developed by NREL [25]. The addition of new types of damages (or the change of an existing one) into the survey is based in the review of failures discussed in the introduction and the information in the international standards IEC PAS 62257-10 [17], IEC 61215-1 [15] and ASTM E1799 [16]. The addition or the change of a failure was focused to give preference to failures that occur in desert climates. The survey's form is composed of 15 sections.

\subsubsection{Procedure}

The order for the complete inspection is as follows:

i. Equipment and tools checklist and optimization.

ii. Perform the visual inspection.

iii. Perform the thermal inspection.

a. Do the thermal inspection at the front surface of the PV module (fill the survey and take thermal images)

iv. Perform the IV curve measurement(s).

\subsubsection{Criteria of Analysis}

The analysis of the recorded data, by means of the three methods detailed in the previous subsection (visual inspection, thermal imaging and IV-curve characterization) was performed based on a detailed review of the literature on the relationships between the failure/degradation modes and possible underlying mechanisms [2]. Among all the abnormalities found in the field test campaign, only a few of them were selected for further analysis according to the following criteria:

1. Abnormalities observed/measured with at least two of the three tools.

2. Abnormalities observed/measured with one tool but showing a considerable deviation from normal conditions, either on their cosmetic appearance, electrical behavior or temperature distribution.

3. Abnormalities that affect those components directly related with the charge carriers generation process.

These criteria are based on the fact that, an integrative analysis overlapping information from different tools is highly desirable, given that, certain failure/degradation modes detected by one tool can be associated with mechanisms, or could be the cause of other failure/degradation modes detected by another tool. For instance, soiling is possible to detect by simple visual inspection, but this tool alone will not provide additional information on the internal behavior of the modules. Furthermore, comparing soiling patterns with IR thermal images can provide information regarding thermal stress associated to soiling deposition or other phenomena. In contrast, other abnormalities, such as hotspots, are practically not possible to detect by bare eye, and a direct impact of this phenomenon, affecting few cells, on the IV-characteristics of the entire module can be complicated to 
infer. However, detection of severe thermal stress and temperature variations between cells within modules, related to other information such as the operating time, operating zone and manufacturer can give valuable insights on the behavior of modules under real operation conditions. Finally, selection of materials directly related with the charge carrier's generation/evacuation is due to fact that, those materials are the candidates for further modification/improvement of composition/features in terms of optoelectronic properties, thermal behavior, and chemical composition to enhance field performance and reduce/delay the impacts of aging and environmental stress.

\section{Results}

\subsection{General Trends}

\subsubsection{Visual Failure Analysis}

In this section general trends of visual, electrical, and thermal abnormalities are shown. They are presented according to zone, in which PV modules were installed, manufacturer and time, which corresponds to years of environmental exposure-whether modules were operating or not. Among the most frequent visual failures founded in the campaign, front glass soiling and backsheet degradation (chalking) are the ones that most showed up. There is an issue, the so-called snail trails, that a module can suffer. It is the discoloration of the module, caused by moisture which can ingress through the backsheet and diffuse to the solar cell surface [26-29]. However, this issue was not found during the field campaign.

In relation to chalking, it was found in three zones: A, B and C. As shown in Figure 4, PV modules with substantial chalking were found in zone B and C. It must be noted that those PV modules had the longest operating period (since 2005) of all 95 inspected modules. Modules with slight chalking at the backsheet were found at zones A and B, where zone $\mathrm{B}$ contains a greater number of modules with slight chalking than zone $\mathrm{A}$, being 22 and 6 , respectively. Chalking of the backsheet seems to be related with locations in the city and young PV modules (3 years of operation). Chalking, which corresponds to a chemical degradation, may be triggered by chemical components of the air in combination with coastal winds. In this case, the city is very close to the coastal area, hence, it is difficult to separate the origin of the failure. In the city, there is high amount of contamination due to public and private transportation that it is combined with salty winds from the coast. For these cases is highly recommended to design PV modules for special conditions (such as corrosive).

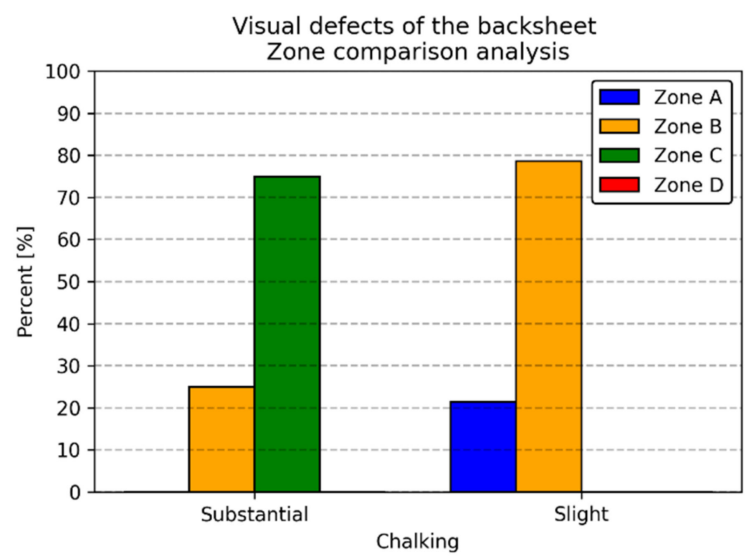

Figure 4. Zone comparison of backsheet failures/defects.

Regarding to the level of soiling, a light soiling has impact on the current but not the voltage. Conversely, heavy soiling influences both, current and voltage, reducing their values [30]. Referring to the inspected modules, light soiling on glass was found in all zones except in zone A, which only contains modules with heavy soiling (see pictures in Figure 5). As shown in Figure 6, zone $C$ is the region with more modules with light soiling $(44.23 \%)$, and zone D is the region with less affected modules (23.08\%). Heavy soiling was 
found in all zones except in zone $\mathrm{D}$, which only contain modules with light soiling. Zone B is the region with more modules with heavy soiling (38.46\%), while zone A and C contain the same number of modules ( $30.77 \%$ each).

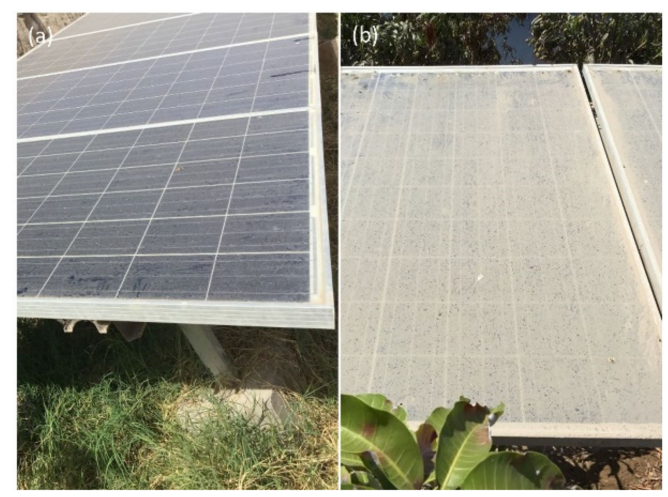

Figure 5. PV module (a) in location 9 (zone B) and (b) location 11 (zone C).

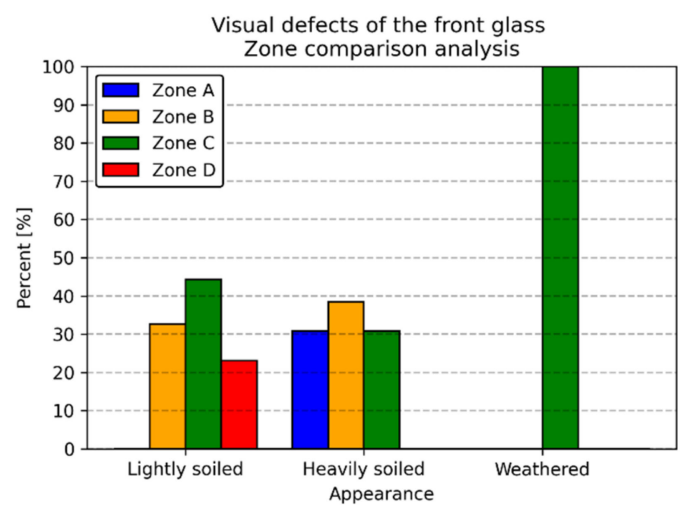

Figure 6. Zone comparison of front glass failures/defects.

Results depending on manufacturer, shown in Figure 7, indicate that the 52 modules with light soiling (Figure 5a) are RISEN (46.15\%), SOLAR WORLD (19.23\%), SUNEL $(17.31 \%)$, HANWHA SOLAR $(7.69 \%)$, SIEMENS (7.69\%) and BP SOLAR $(1.92 \%)$. Regarding to modules with heavy soiling (Figure $5 b)$, they are mainly from SOLAR WORLD $(46.15 \%)$ and ET TOWARDS EXCELLENCE (30.77\%). The rest of the modules with heavy soiling are LUXOR $(15.38 \%)$ and JA SOLAR $(7.69 \%)$.

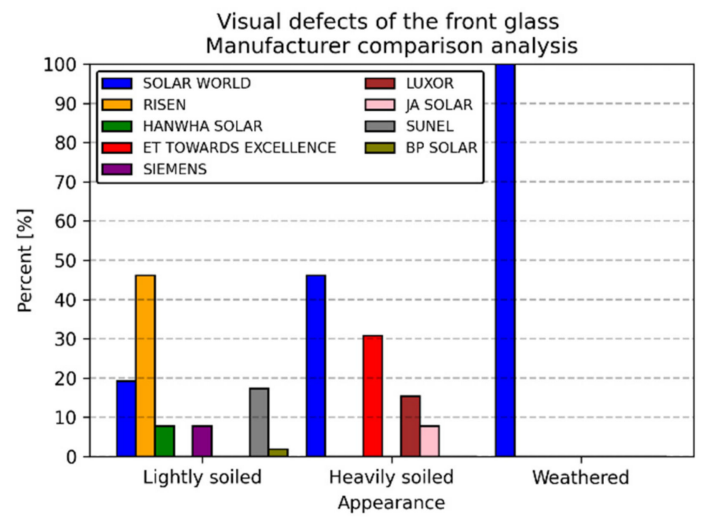

Figure 7. Manufacturer comparison of front glass failures/defects.

Figure 8 shows that soiling is present in PV modules that have been operating since different installation dates: light soiling is mostly seen in modules installed in 2015 (59.57\%), while it is less seen in modules installed in 2005 (8.51\%). Heavy soiling is seen mostly in 
modules installed in $2015(38.46 \%)$ and $2013(30.77 \%)$, and less in modules installed in 2011 and 2012 (15.38\% each). The 2 modules with weathered glass have been operating for 5 years (2013), and the modules with milky discoloration have been operating for 5 years (extensive discoloration) and 6 years (localized discoloration). The term weathering refers to a component of a PV module, which experiments changes to the color or form of that component over a period because of the effects of solar radiation, ultraviolet (UV) light, wind, sand, dust, humidity, temperature, or another weather condition. Note that modules in zone A are in direct contact to humidity. Therefore, it is possible to find heavily soiled modules just after 3 years in zone A and lightly soiled modules after 6 or 13 years in zones B, C, D.

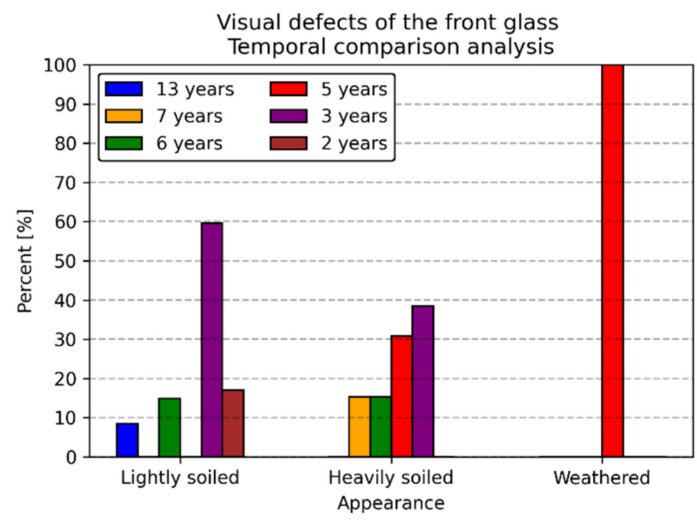

Figure 8. Temporal comparison of front glass failures/defects.

Soiling was found in all visited locations being strongly present in PV modules from the city and the valley. Although studies must be carried out to specify the composition of the soiling, it is highly probable that the soiling of the PV modules installed in the city has different composition than from the soiling of PV modules operating in the valley. Soiling in the valley was light while in the city was sometimes heavy and sometimes light. Since the frequency (and presence) of cleaning is unknown, it cannot be concluded that modules in the city suffer from a stickier soiling than in the valley. The classic solution for soiling will be cleaning but depending on the composition of the soiling it is possible to select a proper coating for the glass in the design of the PV module [31].

\subsubsection{Electrical Parameters Degradation}

All electrical parameters analyzed in this section are corrected to STC conditions. The analysis includes the maximum power $(P)$, open-circuit voltage $\left(V_{o c}\right)$, short-circuit current $\left(I_{s c}\right)$, the voltage and the current in the maximum power point $\left(V_{m p p}\right.$ and $\left.I_{m p p}\right)$, and the fill factor $(F F)$ of the measured I-V curves. Table 1 summarizes the most important degradation values. The $X X_{\text {drop }}$ (in \%), where $X X$ can be any electrical parameter, corresponds to the absolute degradation of such parameter in relation to the nominal value given by the manufacturer. The definition of $D R_{X X}$ (in \%/yr or \%/year) corresponds to the absolute degradation rate of the electrical parameter $X X$ in a yearly basis. Table 1 shows the average and standard deviation for all electrical parameters under study.

Table 1. Average and standard deviation of absolute degradation (in \%) and absolute degradation rate (in \%/year) of $V_{o c}, I_{s c}, P_{m p p}$ and $F F$. Using the average $(\bar{x})$ and standard deviation values $(\sigma)$, the interval for $x$ is $[\bar{x}-\sigma, \bar{x}+\sigma]$.

\begin{tabular}{|c|c|c|c|c|c|c|c|c|}
\hline Parameter & $\begin{array}{c}V_{o c_{\text {drop }}} \\
{[\%]}\end{array}$ & $\begin{array}{l}D R_{V_{o c}} \\
{[\% / y]}\end{array}$ & $\begin{array}{c}I_{S c_{d r o p}} \\
{[\%]}\end{array}$ & $\begin{array}{l}D R_{I_{s c}} \\
{[\% / y]}\end{array}$ & $\begin{array}{c}P_{m p p_{\text {drop }}} \\
{[\%]}\end{array}$ & $\begin{array}{c}D R_{P_{m p p}} \\
{[\% / y]}\end{array}$ & $\begin{array}{c}F F_{\text {drop }} \\
{[\%]}\end{array}$ & $\begin{array}{l}D R_{F F} \\
{[\% / y]}\end{array}$ \\
\hline Average & 3.19 & 0.88 & 8.80 & 2.30 & 13.19 & 3.55 & 4.58 & 1.34 \\
\hline Standard deviation & 2.24 & 0.67 & 5.71 & 1.46 & 6.22 & 1.74 & 5.44 & 1.49 \\
\hline
\end{tabular}


According to Table 1, population under study concentrates its voltage drop in the range $0.95-5.43 \%$. Regarding to the voltage degradation rate, the maximum value is $3.03 \%$ /year, but most of the rates are in the range $0.21-1.55 \%$ /year. According to Figure 9, which shows a temporal analysis of $V_{o c}$, the lowest degradation rates are for modules operating during 5 and 6 years, where the voltage degradation rate is lower than $0.63 \%$ /year. PV modules operating the longest (13 and 7 years).

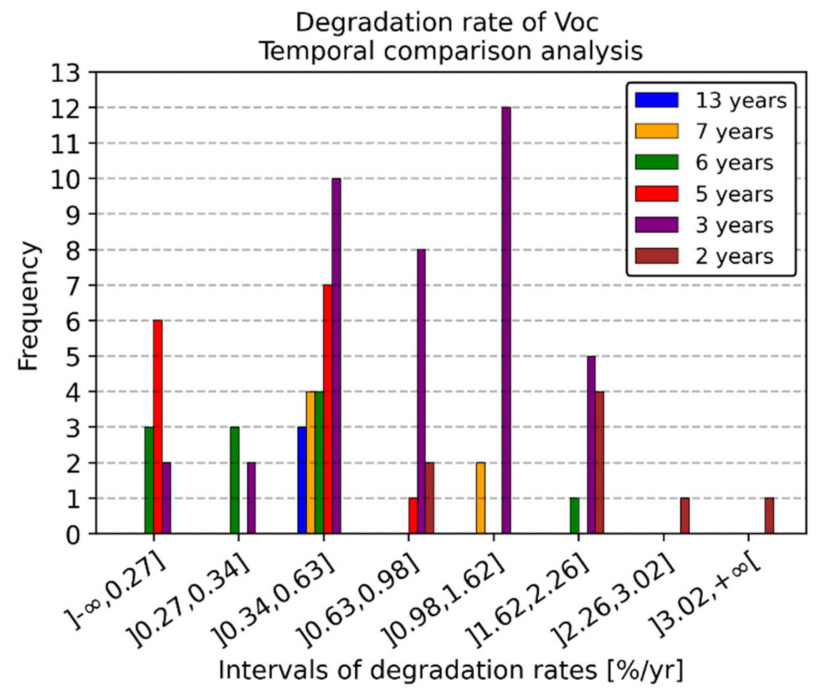

Figure 9. Temporal analysis of the degradation rate of the open-circuit voltage. Modules operating for long periods present lower degradation rates (below $0.63 \%$ /year). Conversely, modules operating the shortest ( 3 and 2 years) exhibit higher voltage degradation rates (up to $1.62 \%$ /year).

In general, as shown in Table 1 , current degradation rates (2.30\%/year) are higher than voltage degradation rates $(0.88 \%$ /year). Current absolute degradation is mainly in the range 3.09-14.51\% while current degradation rates are in the range $0.84-3.76 \%$ /year. At first sight, where Figure 10 shows the distribution of the degradation rates of the current for each zone, it is possible to establish that zone $\mathrm{A}$ is the region with higher degradation rates of current, being $6.76 \%$ /year the largest rate. In contrast, zone D is the one with lower degradation rates with an average of $0.63-2.84 \%$ /year. In zone B and C degradation rates are below 3.38\%/year. Most current degradation rates in zone C are below $0.63 \%$ /year and in the range 1.49-3.38\%/year, while zone B has nearly half of the modules below $2.24 \%$ /year and the other half in the range $2.24-3.97 \%$ /year.

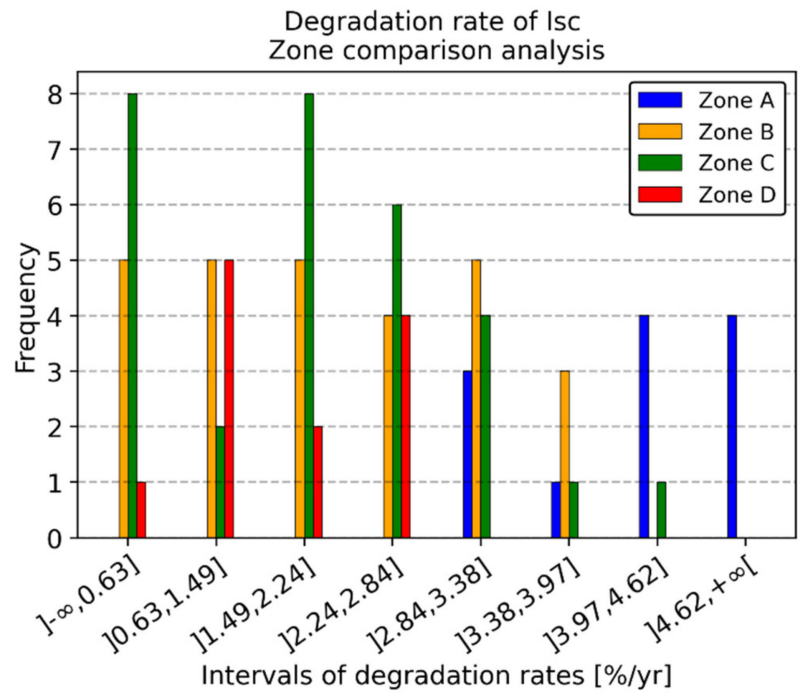

Figure 10. Zone analysis of the degradation rate of the short-circuit current. 
The maximum drop for the $F F$ is $34.35 \%$ and, as it can be seen in Table 1, most of the values are in the range $-0.86 \%-10.02 \%$. Regarding the degradation rates, the maximum value is $6.87 \%$ /year and most of the values are in the range $-0.15-2.83 \%$ /year. Figure 11 indicates that PV modules with lower degradation rates correspond to SOLAR WORLD and SIEMENS (0.87\%/year) while RISEN and ET TOWARDS EXCELLENCE have modules with a wide range of degradation rates (1.16-2.03\%/year). Following are HANWHA SOLAR modules that have degradation rates in the range $2.03-3.71 \%$ /year while SUNEL modules have degradation rates above 3.71\%/year, where the highest is $6.87 \%$ /year. Finally, modules from 4 out of 6 LUXOR modules have low degradation rates below $1.02 \%$ /year, and the rest is above $2.03 \%$ /year.

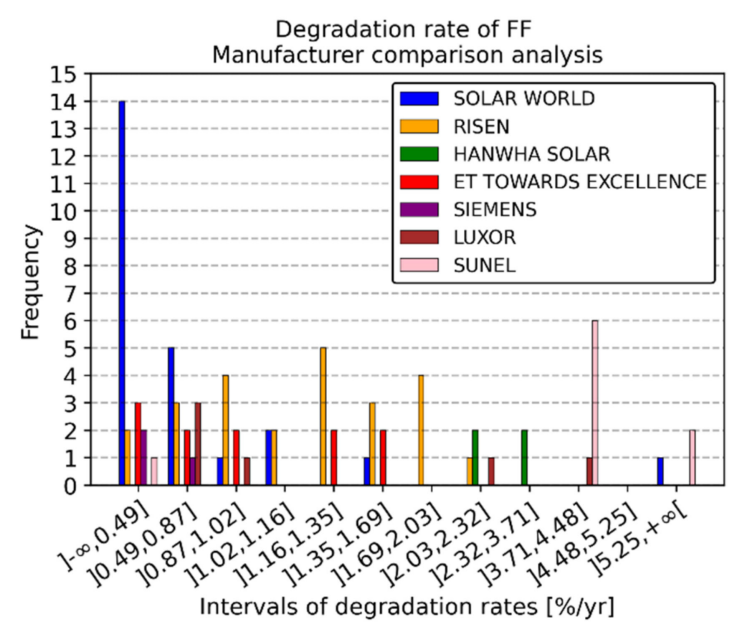

Figure 11. Manufacturer analysis of the degradation rate of the fill factor.

The critical maximum power drop among all modules is $39.08 \%$ with an average in the range 6.97-19.41\%. According to [32], most common guarantees from manufacturers of PV modules indicate that after 25 years the PV module will generate $80 \%$ of the power rated in the nameplate. This can be translated into a maximum power degradation loss of $0.8 \%$ /year. From the 81 modules inspected, only one is within a typical guarantee ( $0.67 \%$ /year). According to Figure 12, the modules operating the longest period (13 and 7 years) are the ones with power degradation rates below $1.26 \%$ /year. Following those operating for 6 years (1.26-4.07\%/year). For those operating 5 years, most degradation rates are below $4.07 \%$ /year. Regarding to modules operating for 3 years, most modules power degradation rates in the range 1.26-4.07\%/year while the rest concentrate in the range $4.07-5.67 \%$ /year. Finally, modules operating for 2 years have power degradation rates above $4.07 \%$ /year.

It can be stated that the power degradation rate values are inversely proportional to the exposure time, i.e., at shorter periods of exposure, the degradation rate is higher. Modules show a fast initial degradation, and during their operating lives they do not degrade so fast. Hence, with more years of exposure, the power degradation rate tends to decrease. 


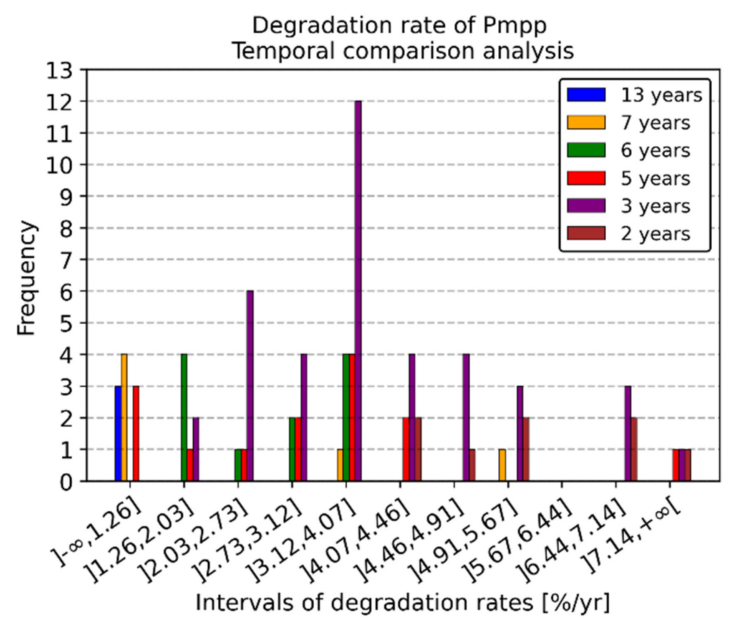

Figure 12. Temporal analysis of the degradation rate of the maximum power point.

\subsubsection{Abnormal Thermal Patterns}

According to the definition of considered thermal abnormalities in Table 2, 6 modules present pattern 2 or 7 but it cannot be determined. Among the abnormalities, only the patterns $2,7,8$ and 11 were found. It must be highlighted that modules were under shortcircuit conditions when the thermal image was taken. In this context, modules with the pattern 2 are not defected. Also, to be able to determine a thermal pattern information regarding the thermal image in combination with the electrical parameters and the visual inspection of the modules were combined to make a conclusion.

Table 2. Definition of thermal abnormalities investigated in 89 of 95 PV modules of the campaign.

\begin{tabular}{ll}
\hline Thermal Pattern & Description \\
\hline Pattern (a) & Modules uniformly warmer than the rest of the modules \\
Pattern (b) & Module contains several hot cells in a random pattern (patchwork pattern) \\
Pattern (c) & Module contains several hot cells in a random pattern (patchwork pattern) \\
Pattern (d) & One substring shows a patchwork pattern \\
Pattern (e) & One substring is uniformly warmer than the rest of the module \\
Pattern (f) & Heated junction box \\
Pattern (g) & Several single cells are warmer, lower parts close to the bottom of the \\
Pattern (h) & module are hotter than middle or upper parts \\
Pattern (i) & Single solar cell warmer (surrounded by cells with normal temperature) \\
Pattern (j) & Part of a cell warmer \\
Pattern (k) & Pointed heating in a random fashion all over the module \\
\hline
\end{tabular}

Figure 13 shows the number of modules having specific thermal patterns, which are sorted by zone; whereas Figure 14 depicts the corresponding thermal patterns [33-36] described in Table 2. In zone A, half of the modules (60) presents a short-circuit pattern and the other half (6) exhibits an uncertain pattern. It cannot be determined whether those 6 modules have a short-circuit pattern or PID, even observing the electrical and visual data. Regarding zone B, $75.9 \%$ of the modules present a short-circuit pattern, 2 modules present PID, 2 modules present a hot cell, 1 module shows a short-circuit pattern and indicating heating due to bird drop. In zone C, $77.8 \%$ of the modules present the short-circuit pattern while the remaining $22.2 \%$ present hot cells. Finally, in zone D all the modules present the patchwork pattern due to short-circuit condition. 


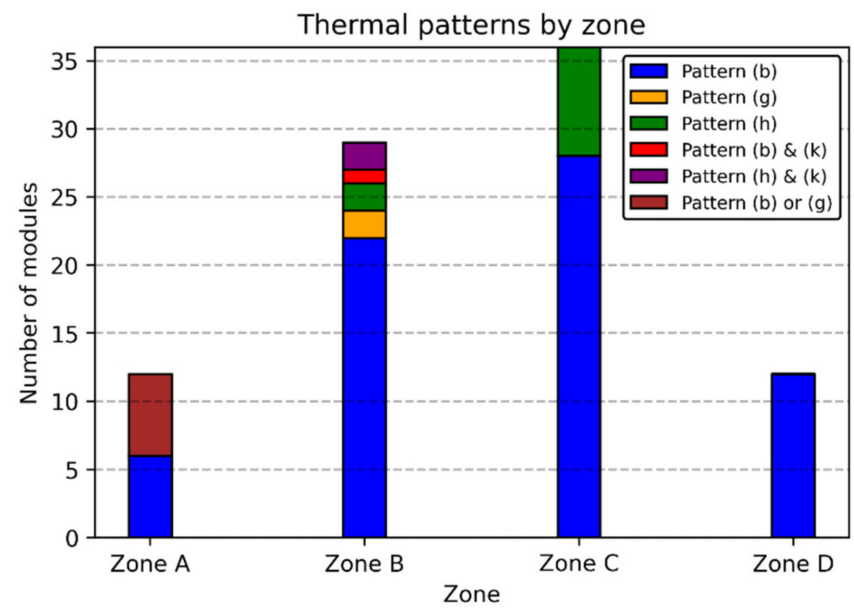

Figure 13. Thermal patterns found within 89 PV modules. Modules are sorted by zone.

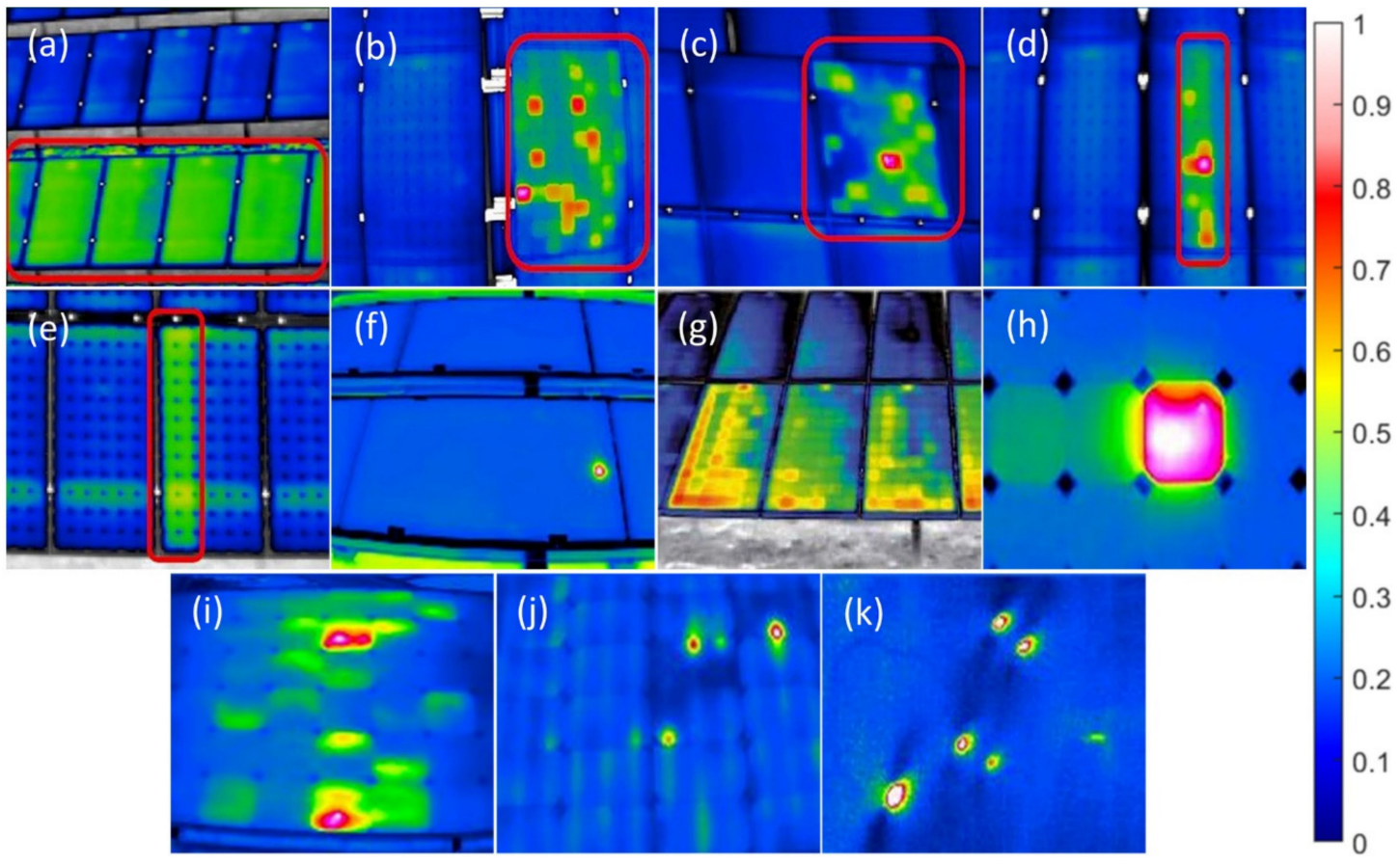

Figure 14. Summary of considered thermal patterns [33-36], which are described in Table 2.

\subsubsection{Zones Overview}

Chalking was found in zones A, B and C, where substantial in zones B and C. This phenomenon is mainly caused by the presence of calcite, which is abundant at the coastal zone of Atacama Desert [31]. Light soiling was found in zones B, C and D; whereas heavy soiling was encountered in zone A. This behavior can be expected as zone A is the one to be closest to the sea and therefore directly exposed to humidity, promoting the adhesion of dust particles [37]. The soiling impact was evidenced in the current output of the modules. For instance, modules in zone A exhibited the largest current degradation; conversely modules in zone $\mathrm{D}$ showed the lowest current degradation. This outcome correlates with the zones with lightly soiled modules (B, C and D) and the zone with heavily soiled modules (A), respectively. The predominant thermal pattern in zones $\mathrm{B}, \mathrm{C}$ and $\mathrm{C}$ was $(\mathrm{b})$; while zone A showed the (b) or $(\mathrm{g})$ pattern. 


\subsection{Specific Abnormalities}

The analysis presented in the previous section can be useful for identifying the general trends regarding the occurrence of failure/degradation modes in modules of the Atacama Desert. However, considering that due to the limited number of existing installations, the sample comprises a limited number of modules, and the fact that it is possible to infer more information from the IDCTool by inspecting the recorded data more thoroughly, a further analysis performed to selected modules according to the criteria given in Section 2.4.3 is provided in this section. According to these selection criteria, the main abnormalities and their impact on the modules' features are considered: soiling, delamination of the EVA encapsulant, discoloration of the front cover glass, partial shading, hotspots, faulty soldering, and cracked cell. Failures/degradation modes assessed using the criteria mentioned above, were related to cosmetic changes, altered electrical performance and/or thermal issues on the sample modules according to the literature $[6,33,38]$. Being dust the most common stressor in desert environments, soiling can be the first cosmetic issue detectable by simple visual inspection.

Ref. [39] concluded that the decrease in the amount of the solar radiation that can reach the solar cells in a module depends on the surface dust density, the dust particle size distribution, and their chemical composition. The light intensity can be reduced by absorption and scattering by the dust particles. Particles having large absorption coefficients (soot and iron oxides with a diameter of $0.2-2.0 \mu \mathrm{m}$ ), absorb incoming photons. Conversely, fine particles having a size, which is comparable to the photon wavelength will scatter light more efficiently than others. The finer particles exhibit a large specific surface area. Therefore, fine particles on module surface can lead to higher energy losses compared with the same surface dust density of large particle deposition.

With respect to a cleaned module, there was a little decrease in quantum efficiency (QE) for lightly soiled modules and a large reduction in QE for heavily soiled modules. In both cases, the comparison is made with respect to the cleaned module. In the latter case, the reduction was dominated by absorption and reflection by the dust layer [40]. Depending on the severity of soiling two main impacts can be observed on the electrical characteristics of soiled modules. For modules slightly soiled, a net reduction in the short circuit current causes a downwards displacement of IV curve in the I axis. In contrast, when modules are affected by severe soiling layers a reduction in their open circuit voltage is also observed [30] (see Table 3). The modules in zone $C$ show higher average temperatures than in the coastal zones, due to higher ambient temperatures and less wind. Modules with severe soiling recovered losses of $P_{m p p}$ when cleaned. Modules in zone $\mathrm{C}$ show greater falls in $I_{s c}$ and $P_{m p p}$. The voltage drops show no correlation with the location of the modules. Light layers of soiling are not shown to cause major stress. Losses in $I_{s c}$ were below $12 \%$. Thermal patterns of soiled modules can also vary given that soiling layers can contribute to mask underlying thermal issues (see Figure 14 for a summary). [41] presents a study, where the temperature at different points of the array was compared. It was found that the temperature of artificially soiled modules was lower than that of the clean modules. The temperature of the soiled module reduced with the increase in dust density. The effect of the dust deposition on the module temperature was mainly attributed to the dust which blocks the incident radiation rather than increasing the heat resistance.

Table 3. Average variation of electrical parameters of heavily soiled modules.

\begin{tabular}{cccccc}
\hline Zone & Soiling Pattern & Average $\mathbf{T}\left[{ }^{\circ} \mathbf{C}\right]$ & $\Delta \mathbf{V}_{\mathbf{o c}}[\%]$ & $\Delta \mathbf{I}_{\mathbf{s c}}[\%]$ & $\Delta \mathbf{P}_{\mathbf{m p p}}[\%]$ \\
\hline A: Coast & Groove deposition & 37.94 & -3.71 & -15.08 & -18.45 \\
B: City coast & Inhomogeneous & 38.36 & -4.69 & -10.06 & -14.22 \\
C: Inner valley & Heavy soiled & 47.93 & -3.47 & -36.53 & -19.08 \\
& Heavy soiled & 42.49 & -4.63 & -55.31 & -63.16 \\
\hline
\end{tabular}


Partial shading of modules, by projected massive objects such as trees, overhead lines or buildings can also cause thermal stress in cells/rows, thus decreasing the overall performance, which are measured as steps on the I-V curve. Usually, partial shading issues can be effectively cleared by removing the shading source but long-term operation under thermal stress can enhance other problems such as decreased shunt resistance and the formation of hotspots.

Delamination of EVA encapsulant can also be detected by simple visual inspection, but varying from slight, bubble shaped delaminated areas around busbars and fingers, to extensively delaminated areas. Thermal patterns associated to delaminated EVA show increased temperature within delaminated areas, while the electrical characterization tends to show a decreased $\mathrm{V}_{\mathrm{oc}}$ and rounding of the knee at $P_{m p p}$. Although discoloration of front cover glass has not been widely documented in literature, several modules operating in the Atacama Desert were found to be affected by degraded transmittance in the glass, which did not improve after cleaning. This issue was directly related with the formation of severe hotspots, reductions in the shunt resistance and even reverse operation of one or more cells. Other hotspots occurrence, not possible to relate with visible changes in the visual inspection are more difficult to relate with changes in series/shunt resistances, but the severity of temperature rising may indicate internal shunts, defective cells, and possible safety issues. Finally, thermal footprints of faulty soldering and cracked cells are associated to inhomogeneous temperature distribution within the affected cells. In the first case, a defective soldering forces the total current to pass though the other soldering, thus producing an abnormal heating in this side with cooling on the other side. In the case of a cracked cell, thermal isolation of the affected areas shows a marked temperature difference within the cell along the cracked area. Electrical measurements show in the first case an increased series resistance, while in the latter the appearance of small plateaus proportional to the cracked areas.

The failure/degradation modes selected in this work are summarized in Table 4, together with possible causes, their visible/measurable effects on the modules and possible mechanisms. It is noticeable that some failure/degradation modes can play a role to trigger other failure/degradation mechanisms. For instance, transient or permanent transmission losses caused either by deposition or interactions between environmental particles with the front cover glass, can trigger the development of hotspots, which can further trigger cell cracking/fractures due to long-term thermal stress. This is important because, isolation of one failure/degradation mode and determination of possible mechanisms is difficult under operating conditions.

Table 4. Summary of the failure/degradation modes studied in this work, with their possible causes, visible/measurable effects on the modules and possible mechanisms, according to the literature [2,42].

\begin{tabular}{|c|c|c|c|}
\hline Failure/Degradation & Possible Causes & Effects & Possible Mechanisms \\
\hline $\begin{array}{l}\text { EVA encapsulant } \\
\text { delamination }\end{array}$ & $\begin{array}{ll}\text { - } & \text { Humidity }+ \text { moisture } \\
\text { - } & \text { UV sensitivity of } \\
\text { - } & \text { adhesives } \\
\text { Defective adhesion } \\
\text { during manufacturing } \\
\text { - } \quad \text { External agents } \\
\text { contamination }\end{array}$ & $\begin{array}{ll}- & \text { Moisture ingress } \\
- & \text { Corrosion } \\
- & \text { Transmittance losses } \\
- & \text { Power losses } \\
- & \text { Abnormal temperature } \\
& \text { distributions }\end{array}$ & $\begin{array}{ll}\text { - } & \text { Photochemical reactions } \\
\text { - } & \text { Chemical gradients on } \\
\text { the interfaces } \\
\text { (EVA/glass, EVA/cells) } \\
\text { - } \quad \text { Thermo-mechanical } \\
\text { stress } \\
\text { - } \quad \text { Severe electric mismatch }\end{array}$ \\
\hline
\end{tabular}


Table 4. Cont.

\begin{tabular}{|c|c|c|c|}
\hline Failure/Degradation & Possible Causes & Effects & Possible Mechanisms \\
\hline Hotspots & $\begin{array}{ll}\text { - } & \begin{array}{l}\text { Different thermal } \\
\text { expansion coefficients }\end{array} \\
\text { between cell } \\
\text { components } \\
\text { - } & \text { Shading, soiling } \\
\text { - } & \begin{array}{l}\text { Defective cells (cracks, } \\
\text { fractures) }\end{array} \\
\text { - } & \text { Low shunt resistance } \\
\text { - } & \text { Faulty bypass diode }\end{array}$ & $\begin{array}{ll}- & \text { Burns } \\
- & \text { Lower total current } \\
- & \text { Damages on EVA/glass } \\
- & \text { Encapsulant } \\
& \text { discoloration } \\
- & \text { Power loss } \\
- & \text { Thermal stress among } \\
& \text { cells }\end{array}$ & $\begin{array}{l}\text { - Thermal stress on } \\
\text { defective/lower quality } \\
\text { cells } \\
\text { - Thermal stress between } \\
\text { cells and metallic } \\
\text { components } \\
\text { - Cell internal shunts } \\
\text { - } \quad \begin{array}{l}\text { Non-negligible current } \\
\text { mismatch between cells }\end{array}\end{array}$ \\
\hline $\begin{array}{l}\text { Soiling } \\
\text { - } \quad \text { Glass discoloration } \\
-\quad \text { Weathering }\end{array}$ & $\begin{array}{ll}\text { - } & \text { Poor tilting of modules } \\
\text { - } & \text { Defective cleaning } \\
\text { protocols } \\
\text { - } & \text { Long term exposure in } \\
\text { dusty environments }\end{array}$ & $\begin{array}{ll}\text { - } & \text { Transient or permanent } \\
\text { transmittance losses } \\
\text { - } & \text { Power losses } \\
\text { - } & \text { Cosmetic changes } \\
\text { Permanent allocation of } \\
\text { particles over the } \\
\text { modules }\end{array}$ & $\begin{array}{l}\text { - Gradual deposition of } \\
\text { soiling layers on the } \\
\text { front cover glass } \\
\text { Physicochemical } \\
\text { reactions between } \\
\text { environmental particles } \\
\text { and front cover } \\
\text { components }\end{array}$ \\
\hline $\begin{array}{ll}\text { - } & \text { Faulty soldering } \\
\text { - } & \text { Fractured cell }\end{array}$ & $\begin{array}{l}\text { - Defective fabrication, } \\
\text { transport and/or } \\
\text { handling } \\
\text { - } \quad \text { Long-term thermal } \\
\text { stress }\end{array}$ & $\begin{array}{ll}\text { - } & \begin{array}{l}\text { Loss of } \\
\text { generation/evacuation }\end{array} \\
\text { of charge carriers } \\
\text { - } \quad \text { Uneven temperature } \\
\text { distribution } \\
\text { - } \quad \begin{array}{l}\text { Increased series } \\
\text { resistance }\end{array}\end{array}$ & 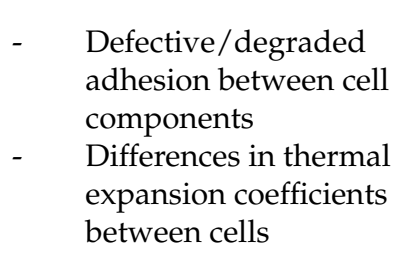 \\
\hline
\end{tabular}

\section{Conclusions}

In this work, the Inspection Data Collection Tool (IDCTool) was designed as a low-cost approach and implemented for photovoltaic (PV) modules installed in the north part of the Atacama Desert in Chile. The IDCTool combines novel features of compatibility and current standards, efficient mobile- equipment and tools, clear cost-effective procedures/protocols for non-expert users. A total of $95 \mathrm{PV}$ modules were inspected, which were distributed in different zones, denoted as A (coast), B (city), C (inner valley) and D (desert). The IDCTool consists mainly of a visual inspection, thermal images, and electrical measurements. It was possible to characterize the failure/degradations concerning to three elements of the PV modules: glass of the front side, encapsulant (ethylene-vinyl acetate (EVA) and solar cells. There were 7 abnormalities examined: soiling, discoloration of PV glass, encapsulant's delamination, hotspots, partial shading, solar cell breakage and defective soldering. Both cell breakage and soldering were deduced from the thermal profiles and explained qualitatively. Soiling was the most frequent problem appearing in different levels and deposition patterns and revealing a relationship between dust particle deposition and the installation site. The decrease in the short-circuit current due to soiling correlated with the reduction of the maximum power. In the case of modules with very thick soiling layers, the open circuit voltage was also reduced. Conversely, soiling, and partial shading did not cause an excess of heat in the solar cells. In addition, hotspots found in more than $50 \%$ of the modules of the total sample. The loss in transmittance of glass as well as internal failures of the solar cells such as shunts or low parallel resistance could explain significant increases in the solar cells' temperature. Furthermore, chemical reactions between environmental agents such as humidity, airborne dust particles and the surface of modules could be implied, since variations in the composition of glass were observed. Degradation of PV modules caused by ultraviolet irradiance was not evidenced. However, it may contribute as a catalyst agent provided the existence of other environmental stressors. 
Author Contributions: Conceptualization, I.D. and R.P.-B.; Data curation, P.V. and I.D.; Formal analysis, P.V. and I.D.; Funding acquisition, R.P.-B.; Investigation, I.D.; Methodology, I.D.; Project administration, R.P.-B.; Resources, R.P.-B.; Software, A.T.; Supervision, P.F. and C.P.; Validation, P.V.; Visualization, P.V., I.D., P.F. and A.T.; Writing-original draft, P.F.; Writing-review \& editing, P.F., C.P. and R.P.-B. All authors have read and agreed to the published version of the manuscript.

Funding: The authors acknowledge the ANID/FONDECYT/11190289 project "Performance Analysis of Photovoltaic Materials and Devices exposed to the Ultraviolet Light of Atacama Desert", the ANID/FONDECYT/1211968 project "Comprehensive integration of decentralized solutions in energy system planning" and the ANID/FONDAP/15110019 project "Solar Energy Research Center" SERC-Chile.

Institutional Review Board Statement: Not applicable.

Informed Consent Statement: Not applicable.

Data Availability Statement: Data available on request.

Acknowledgments: Authors acknowledge Sebastián Rodriguez for his support in image processing.

Conflicts of Interest: The authors declare no conflict of interest.

\section{Appendix A}

In this appendix section, information regarding electrical parameters of $\mathrm{PV}$ is provided in Table A1 and coordinates for the locations in Table A2.

Table A1. Summary of electrical parameters of all 10 PV modules models inspected in Arica.

\begin{tabular}{|c|c|c|c|c|c|c|c|c|c|}
\hline Manufacturer & Model & $\begin{array}{l}V_{o c} \\
{[\mathbf{V}]}\end{array}$ & $\begin{array}{c}V_{m p p} \\
{[\mathrm{~V}]}\end{array}$ & $\begin{array}{l}I_{s c} \\
{[A]}\end{array}$ & $\begin{array}{r}I_{m p p} \\
{[\mathrm{~A}]}\end{array}$ & $\begin{array}{c}P_{m p p} \\
{[W]}\end{array}$ & $\begin{array}{l}\mathrm{TC} I_{s c} \\
{[\mathrm{~A} / \mathrm{K}]}\end{array}$ & $\begin{array}{l}\mathrm{TC} V_{o c} \\
{[\mathrm{~V} / \mathrm{K}]}\end{array}$ & $\begin{array}{l}R_{s} \\
{[\Omega]}\end{array}$ \\
\hline BP SOLAR & BP3160N & 44.20 & 35.10 & 4.80 & 4.55 & 160 & 0.0031 & -0.1591 & 0.618 \\
\hline LUXOR & LX-230P/156-60+ & 37.55 & 30.10 & 8.39 & 7.81 & 235 & 0.0050 & -0.1187 & 0.276 \\
\hline SOLAR WORLD & $\begin{array}{l}\text { Sunmodule SW } \\
250 \text { poly }\end{array}$ & 37.60 & 30.50 & 8.81 & 8.27 & 252 & 0.0071 & -0.1391 & 0.245 \\
\hline RISEN & SYP250P & 37.30 & 30.30 & 8.90 & 8.27 & 251 & 0.0029 & -0.1230 & 0.486 \\
\hline $\begin{array}{l}\text { ET TOWARDS } \\
\text { EXCELLENCE }\end{array}$ & ET-P660250WW & 37.47 & 30.34 & 8.76 & 8.24 & 250 & 0.0035 & -0.1273 & 0.252 \\
\hline JA SOLAR & JAP6-60-260/3BB & 37.98 & 30.63 & 9.04 & 8.49 & 260 & 0.0052 & -0.1253 & 0.253 \\
\hline SUNEL & SNM-M200(72) & 48.48 & 37.19 & 5.89 & 5.36 & 199 & 0.0025 & -0.1696 & 0.355 \\
\hline $\begin{array}{l}\text { HANWHA } \\
\text { SOLAR }\end{array}$ & HSL60P6-PB-1-250 & 37.70 & 30.40 & 8.79 & 8.23 & 250 & 0.0043 & -0.1168 & 0.355 \\
\hline SUNEL & SNM-P250(60) & 37.68 & 30.90 & 8.89 & 8.09 & 250 & 0.0035 & -0.1243 & 0.355 \\
\hline SIEMENS & SM55 & 21.70 & 17.40 & 3.45 & 3.15 & 55 & 0.0012 & -0.0770 & 0.355 \\
\hline
\end{tabular}


Table A2. Summary of inspected zones.

\begin{tabular}{|c|c|c|c|c|c|c|}
\hline \multirow{2}{*}{ Zone } & \multicolumn{3}{|c|}{ Location } & \multicolumn{3}{|c|}{ PV Modules } \\
\hline & Number & Latitude & Longitude & Manufacturer & Number & Estimated Deployment Date \\
\hline \multirow[b]{2}{*}{$\mathrm{A}$} & 2 & -18.4136111 & -70.3152778 & SOLAR WORLD & 6 & 2013 \\
\hline & 3 & -18.4460410 & -70.2935220 & $\begin{array}{l}\text { ET TOWARDS } \\
\text { EXCELLENCE }\end{array}$ & 6 & 2015 \\
\hline \multirow{6}{*}{ B } & 4 & -18.4840700 & -70.2915800 & $\begin{array}{l}\text { ET TOWARDS } \\
\text { EXCELLENCE }\end{array}$ & 6 & 2015 \\
\hline & 5 & -18.4883630 & -70.2956970 & SIEMENS & 2 & No information \\
\hline & 6 & -18.4887710 & -70.2957020 & BP SOLAR & 1 & No information \\
\hline & \multirow{2}{*}{7} & \multirow{2}{*}{-18.4895600} & \multirow{2}{*}{-70.2951670} & LUXOR & 6 & 2011 \\
\hline & & & & JA SOLAR & 3 & 2015 \\
\hline & 8 & -18.4878280 & -70.2881770 & RISEN & 16 & 2015 \\
\hline \multirow{8}{*}{$\mathrm{C}$} & 9 & -18.5022550 & -70.2529490 & SUNEL(60) & 8 & 2016 \\
\hline & 10 & -18.5166667 & -70.2222222 & SOLAR WORLD & 2 & 2013 \\
\hline & 11 & -18.5193680 & -70.2043570 & SOLAR WORLD & 6 & 2013 \\
\hline & 12 & -18.5544860 & -70.1210200 & SOLAR WORLD & 4 & No information \\
\hline & 13 & -18.4454440 & -70.0742150 & SOLAR WORLD & 6 & 2012 \\
\hline & \multirow{2}{*}{14} & \multirow{2}{*}{-18.4302340} & \multirow{2}{*}{-70.0948360} & SUNEL(72) & 1 & 2012 \\
\hline & & & & SOLAR WORLD & 6 & 2012 \\
\hline & 15 & -18.7665360 & -70.2316310 & SIEMENS & 4 & 2005 \\
\hline \multirow{2}{*}{$\mathrm{D}$} & \multirow{2}{*}{1} & \multirow{2}{*}{-18.3549320} & \multirow{2}{*}{-70.2977860} & HANWHA SOLAR & 4 & 2015 \\
\hline & & & & RISEN & 8 & 2015 \\
\hline
\end{tabular}




\section{Appendix B}

In this appendix section, the visual inspection form used in this work is shown.

\section{Visual inspection form}

1. Site information

\begin{tabular}{|ll|ll|} 
Installation address & $:$ & Latitude & $:$ \\
Longitude & $:$ \\
ID (Solar MAP) & $:$ & & \\
Altitude & \\
Date $(\mathrm{dd} / \mathrm{mm} / \mathrm{yy})$ & $:$ \\
\hline
\end{tabular}

BEGIN INSPECTION AT THE BACK SIDE OF THE MODULE

2. Module data

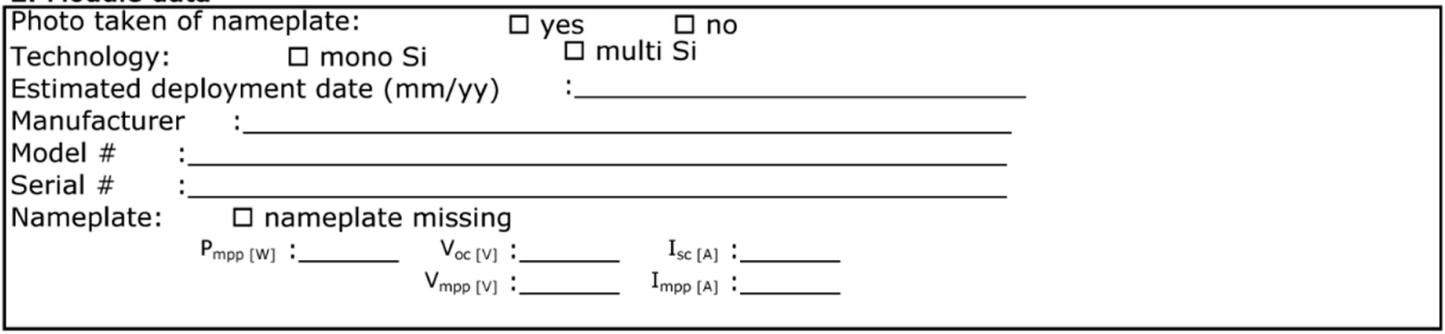

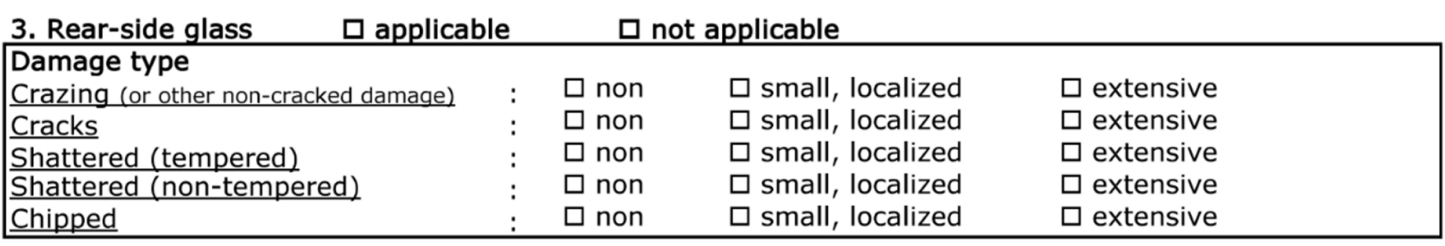

4. Backsheet (polymer)

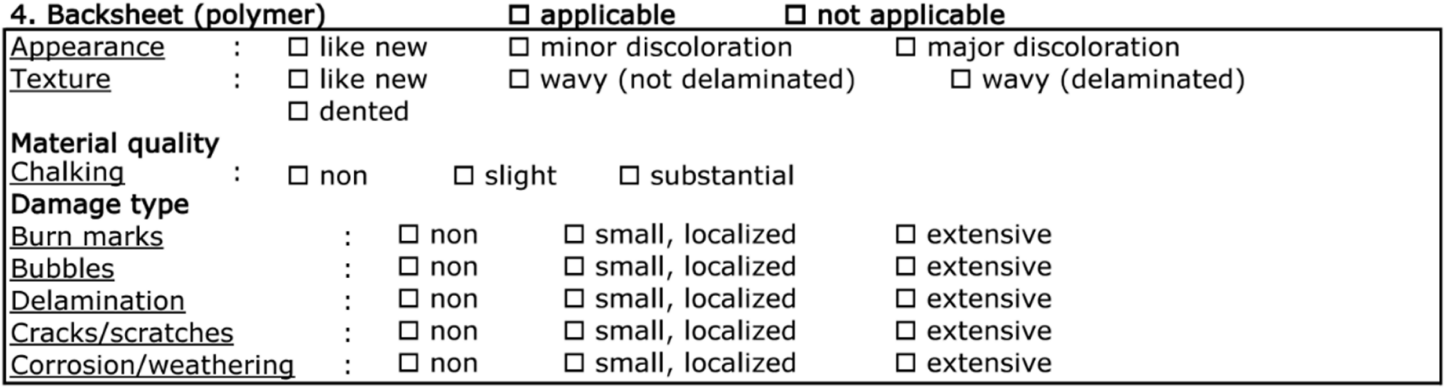

\section{Wires $\square$ applicable $\square$ not applicable}

\begin{tabular}{|c|c|c|c|}
\hline $\begin{array}{l}\text { Appearance } \\
\text { Damage type }\end{array}$ & $\begin{array}{l}: \\
:\end{array}$ & $\begin{array}{l}\text { like new } \square \text { pliable, but degraded } \\
\square \text { cracked/disintegrated insulation } \\
\square \text { cuts/marks }\end{array}$ & $\begin{array}{l}\square \text { embrittled } \\
\square \text { burnt } \square \text { corroded }\end{array}$ \\
\hline
\end{tabular}




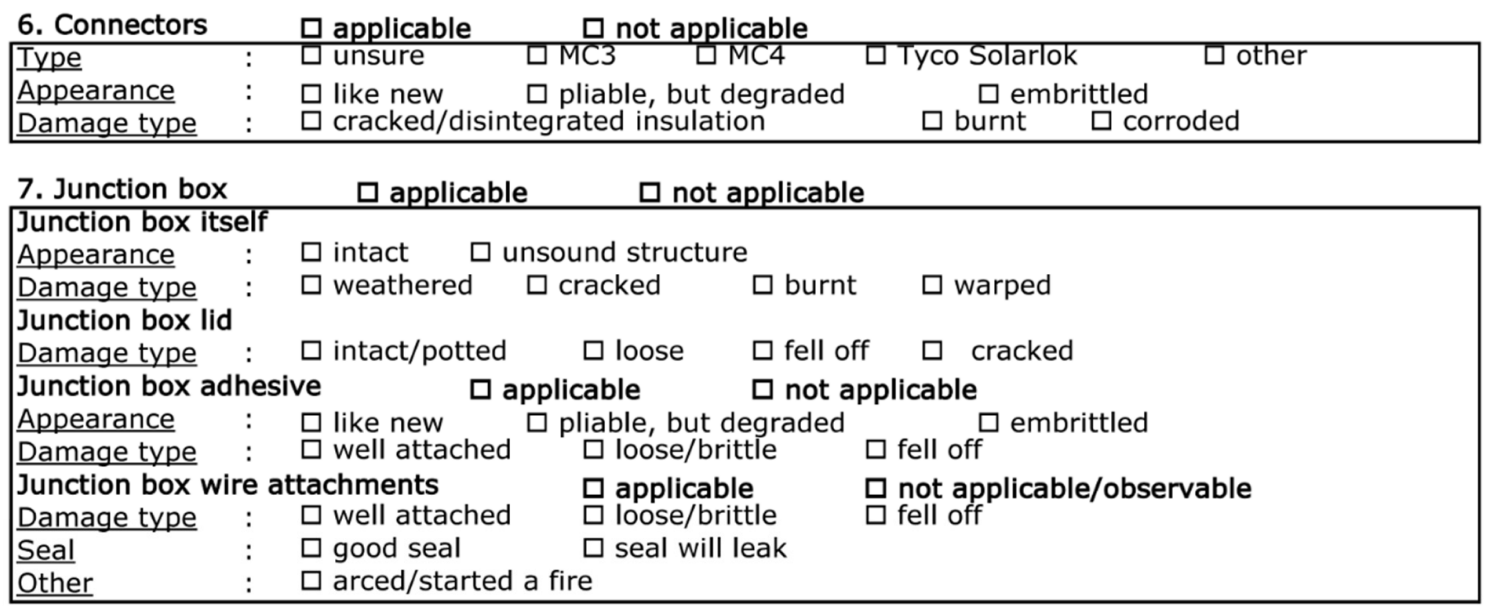

8. Frame grounding $\quad \square$ applicable $\quad \square$ not applicable
\begin{tabular}{|lcccc|}
\hline Original state & $:$ & $\square$ wired ground & $\square$ resistive ground $\square$ no ground $\square$ unknown \\
Appearance & $:$ & $\square$ not applicable & $\square$ like new $\square$ minor corrosion $\square$ major corrosion \\
Function & $:$ & $\square$ well grounded & $\square$ no connection & \\
\hline
\end{tabular}

Photos taken of : $\quad \square$ back, label and junction box

\section{CONTINUE INSPECTION AT THE FRONT SIDE OF THE MODULE}

9. Frame
\begin{tabular}{|lcccc|} 
Appearance & applicable & $\square$ not applicable & \\
Damage type & $:$ & $\square$ like new & $\square$ damaged $\quad \square$ missing & \\
\hline $\begin{array}{l}\text { Frame adhesive } \\
\text { Damage type }\end{array}$ & $:$ & $\square$ like new/not visible & $\square$ degraded & \\
\hline
\end{tabular}

\section{Frameless edge seal $\square$ applicable $\square$ not applicable}

\begin{tabular}{|lcll|}
\hline Appearance & $:$ & $\square$ like new $\quad \square$ discolored & $\square$ visibly degraded \\
Damage type & $:$ & $\square$ squeezed/pinched out & $\square$ moisture penetration \\
& & $\square$ delaminated (small, localized) & $\square$ delaminated (extensive) \\
\hline
\end{tabular}

11. Glass/polymer (front)

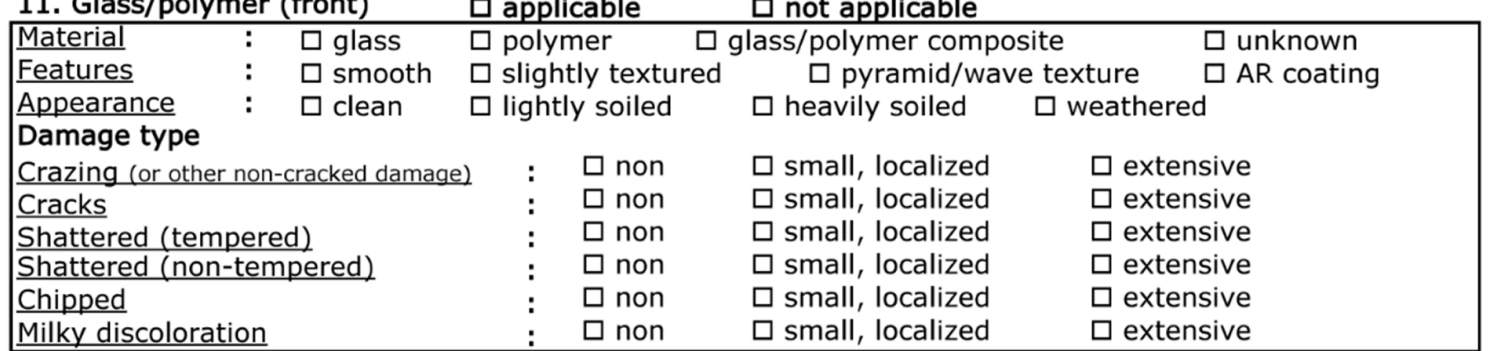




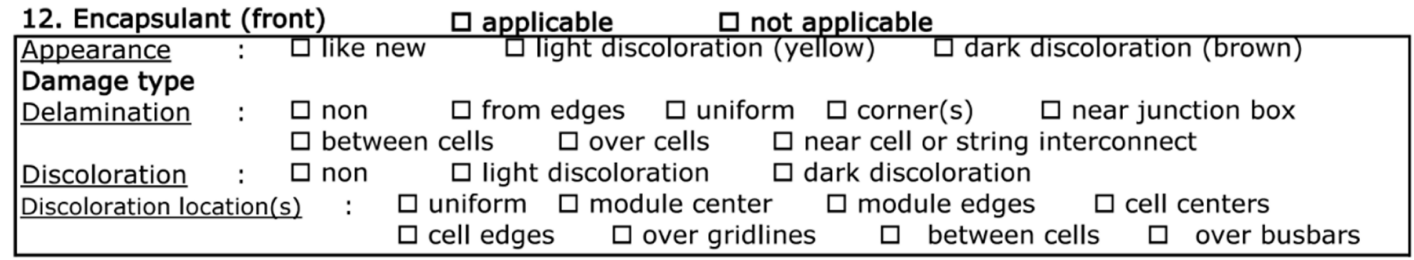

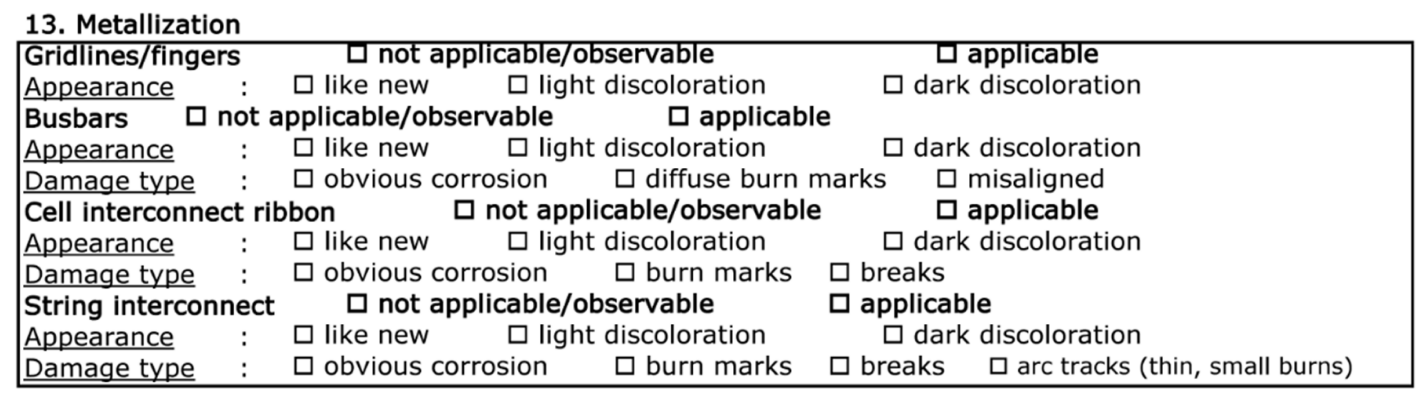

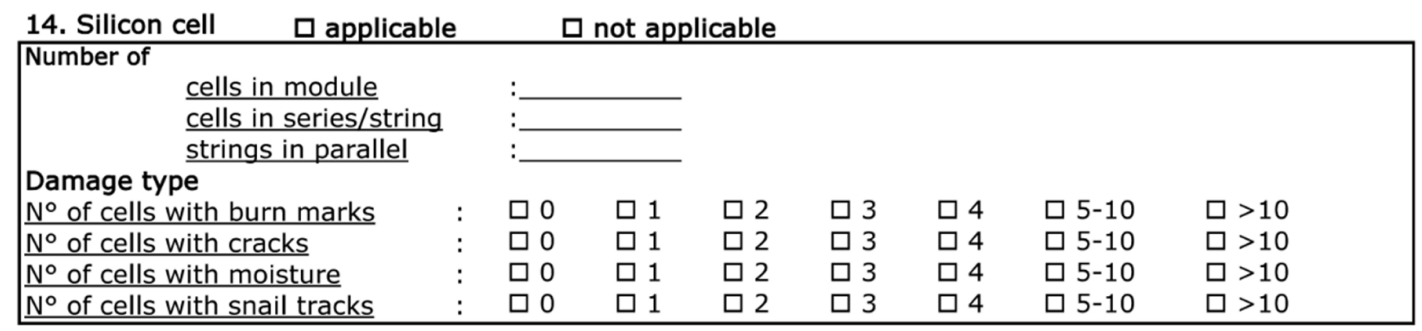

Photos taken of : $\quad \square$ front side END OF VISUAL INSPECTION

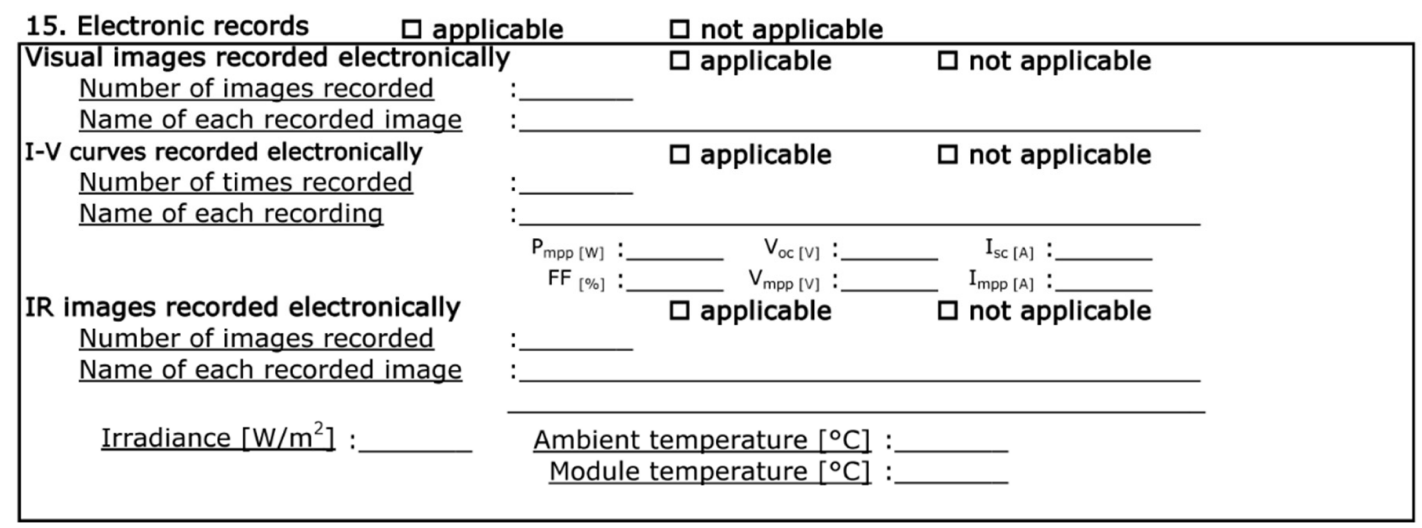

\section{References}

1. Cordero, R.R.; Damiani, A.; Jorquera, J.; Sepúlveda, E.; Caballero, M.; Fernandez, S.; Feron, S.; Llanillo, P.J.; Carrasco, J.; Laroze, D.; et al. Ultraviolet radiation in the Atacama Desert. Antonie Leeuwenhoek 2018, 111, 1301-1313. [CrossRef] [PubMed]

2. Köntges, M.; Oreski, G.; Jahn, U.; Herz, M.; Hacke, P.; Weiss, K.-A.; Razongles, G.; Paggi, M.; Parlevliet, D.; Tanahashi, T.; et al. Assessment of Photovoltaic Module Failures in the Field. 2017. Available online: http:/ /www.iea-pvps.org/index.php?id=92 \&eID $=$ dam_frontend_push\&docID $=4059$ (accessed on 22 April 2021).

3. Ogbomo, O.O.; Amalu, E.H.; Ekere, N.; Olagbegi, P. A review of photovoltaic module technologies for increased performance in tropical climate. Renew. Sustain. Energy Rev. 2017, 75, 1225-1238. [CrossRef]

4. Walsh, T.M.; Xiong, Z.; Khoo, Y.S.; Tay, A.A.; Aberle, A.G. Singapore Modules-Optimised PV Modules for the Tropics. Energy Procedia 2012, 15, 388-395. [CrossRef]

5. National Energy Commision (CNE): Renewable Energy Report N54, Santiago. 2021. Available online: https://www.cne.cl/wpcontent/uploads/2021/02/RMensual_ERNC_v202102.pdf (accessed on 22 April 2021).

6. Jordan, D.C.; Silverman, T.J.; Wohlgemuth, J.H.; Kurtz, S.R.; VanSant, K.T. Photovoltaic failure and degradation modes. Prog. Photovolt. Res. Appl. 2017, 25, 318-326. [CrossRef]

7. Vásquez, P.; Palma-Behnke, R.; Devoto, I. Analysis of Failure and Degradation Modes of Small-Scale Photovoltaic Power Plants in Rural Communities of the Atacama Desert. Proc. ISES Solar World Congr. 2019, 2019, 2514-2525. [CrossRef] 
8. Kuitche, J.M.; Pan, R.; Tamizhmani, G. Investigation of Dominant Failure Mode(s) for Field-Aged Crystalline Silicon PV Modules under Desert Climatic Conditions. IEEE J. Photovolt. 2014, 4, 814-826. [CrossRef]

9. Berman, D.; Biryukov, S.; Faiman, D. EVA laminate browning after 5 years in a grid-connected, mirror-assisted, photovoltaic system in the Negev desert: Effect on module efficiency. Sol. Energy Mater. Sol. Cells 1995, 36, 421-432. [CrossRef]

10. Shrestha, S.M.; Mallineni, J.K.; Yedidi, K.R.; Knisely, B.; Tatapudi, S.; Kuitche, J.; Tamizhmani, G. Determination of Dominant Failure Modes Using FMECA on the Field Deployed c-Si Modules Under Hot-Dry Desert Climate. IEEE J. Photovolt. 2015, 5, 174-182. [CrossRef]

11. Yedidi, K.; Tatapudi, S.; Mallineni, J.; Knisely, B.; Kutiche, J.; Tamizhmani, G. Failure and Degradation Modes and Rates of PV Modules in a Hot-Dry Climate: Results After 16 years of Field Exposure. In Proceedings of the IEEE 40th Photovoltaic Specialist Conference (PVSC), Denver, CO, USA, 8-13 June 2014; pp. 3245-3247.

12. Mallineni, J.; Knisely, B.; Yedidi, K.; Tatapudi, S.; Kuitche, J.; Tamizhmani, G. Evaluation of 12-Year-Old PV Power Plant in Hot-Dry Desert Climate: Potential Use of Field Failure Metrics for Financial Risk Calculation. In Proceedings of the 2014 IEEE 40th Photovoltaic Specialist Conference, Denver, CO, USA, 8-13 June 2014; pp. 3366-3371.

13. Suleske, A.; Singh, J.; Kuitche, J.; Tamizh-Mani, G. Performance degradation of grid-tied photovoltaic modules in a hot-dry climatic condition. SPIE Solar Energy Technol. 2011, 8112, 81120. [CrossRef]

14. Singh, J.; Belmont, J.; Tamizhmani, G.; Singh, J. Degradation analysis of 1900 PV modules in a hot-dry climate: Results after 12 to 18 years of field exposure. In Proceedings of the IEEE 39th Photovoltaic Specialists Conference (PVSC), Tampa, FL, USA, 16-21 June 2013; pp. 3270-3275. [CrossRef]

15. International Electrotechnical Comission (IEC). IEC 61215-1:2016 Terrestrial Photovoltaic (PV) Modules-Design Qualification and Type of Approval_-Part 1: Test Requirements; International Electrotechnical Comission (IEC): Geneva, Switzerland, 2016.

16. ASTM International. Standard Practice for Visual Inspections of Photovoltaic Modules. In E1799; ASTM International: West Conshohocken, PA, USA, 2012. [CrossRef]

17. International Electrotechnical Comission (IEC). IEC PAS 62257-10:2017 Recommendations for Renewable Energy and Hybrid Systems for Rural Electrification -Part 10: Silicon Solar Module Visual Inspection Guide; International Electrotechnical Commission (IEC): Geneva, Switzerland, 2017.

18. Packard, C.E.; Wohlgemuth, J.H.; Kurtz, S.R. Development of a Visual Inspection Data Collection Tool for Evaluation of Fielded PV Module Condition; Office of Scientific and Technical Information (OSTI): Oak Ridge, TN, USA, 2012; pp. 1-52.

19. International Electrotechnical Comission (IEC). IEC 60904-1 Photovoltaic Devices_Part 1: Measurement of Photovoltaic Current-Voltage Characteristics, 2nd ed.; International Electrotechnical Commission (IEC): Geneva, Switzerland, 2006.

20. ASTM International. Standard Test methods for Electrical Performance of Nonconcentrator Terrestrial Photovoltaic Modules and Arrays Using Reference Cells. In E1036; ASTM International: West Conshohocken, PA, USA, 2015. [CrossRef]

21. International Electrotechnical Comission (IEC). IEC/TS 62446-3 Photovoltaic (PV) systems—Requirements for Testing, Documentation and Maintenance - Part 3: Photovoltaic Modules and Plants-Outdoor Infrared Thermography; International Electrotechnical Commission (IEC): Geneva, Switzerland, 2017.

22. Jahn, U.; Herz, M.; Rheinland, T. Review on Infrared (IR) and Electroluminescence (EL) Imaging for Photovoltaic Field Applications; International Energy Agency (IEA): Paris, France, 2018.

23. Kottek, M.; Grieser, J.; Beck, C.; Rudolf, B.; Rubel, F. World Map of the Köppen-Geiger climate classification updated. Meteorol. Z. 2006, 15, 259-263. [CrossRef]

24. International Electrotechnical Comission (IEC). IEC 61829 Photovoltaic (PV) Array-On-Site Measurement of Current-Voltage Characteristics; International Electrotechnical Commission (IEC): Geneva, Switzerland, 2015.

25. Packard, C.E.; Wohlgemuth, J.H.; Kurtz, S.R. Development of a Visual Inspection Checklist for Evaluation of Fielded PV Module Condition. In Proceedings of the PV Module Reliability Workshop, Golden, CO, USA, 28 February-2 March 2012.

26. Dolara, A.; Lazaroiu, G.C.; Leva, S.; Manzolini, G.; Votta, L. Snail Trails and Cell Microcrack Impact on PV Module Maximum Power and Energy Production. IEEE J. Photovolt. 2016, 6, 1269-1277. [CrossRef]

27. Kim, N.; Hwang, K.-J.; Kim, D.; Lee, J.H.; Jeong, S.; Jeong, D.H. Analysis and reproduction of snail trails on silver grid lines in crystalline silicon photovoltaic modules. Sol. Energy 2016, 124, 153-162. [CrossRef]

28. Fan, J.; Ju, D.; Yao, X.; Pan, Z.; Terry, M.; Gambogi, W.; Stika, K.; Liu, J.; Tao, W.; Liu, Z.; et al. Study on snail trail formation in PV module through modeling and accelerated aging tests. Sol. Energy Mater. Sol. Cells 2017, 164, 80-86. [CrossRef]

29. Meyer, S.; Timmel, S.; Richter, S.; Werner, M.; Gläser, M.; Swatek, S.; Braun, U.; Hagendorf, C. Silver nanoparticles cause snail trails in photovoltaic modules. Sol. Energy Mater. Sol. Cells 2014, 121, 171-175. [CrossRef]

30. Maghami, M.R.; Hizam, H.; Gomes, C.; Radzi, M.A.; Rezadad, M.I.; Hajighorbani, S. Power loss due to soiling on solar panel: A review. Renew. Sustain. Energy Rev. 2016, 59, 1307-1316. [CrossRef]

31. Ferrada, P.; Olivares, D.; Del Campo, V.; Marzo, A.; Araya, F.; Cabrera, E.; Llanos, J.; Correa-Puerta, J.; Portillo, C.; Silva, D.R.; et al. Physicochemical characterization of soiling from photovoltaic facilities in arid locations in the Atacama Desert. Sol. Energy 2019, 187, 47-56. [CrossRef]

32. Jordan, D.C.; Kurtz, S.R.; VanSant, K.; Newmiller, J. Compendium of photovoltaic degradation rates. Prog. Photovolt. Res. Appl. 2016, 24, 978-989. [CrossRef] 
33. Köntges, M.; Kurtz, S.; Packard, C.E.; Jahn, U.; Berger, K.; Kato, K.; Friesen, T.; Liu, H.; van Iseghem, M. Performance and Reliability of Photovoltaic Systems Subtask 3.2: Review of Failures of Photovoltaic Modules: IEA PVPS Task 13: External Final Report IEA-PVPS; International Energy Agency (IEA): Paris, France, 2014.

34. Jahn, U.; Köntges, M.; Parlevliet, D.; Paggi, M.; Tsanakas, I.; Stein, J.; Berger, K.; Ranta, S.; French, R.; Richter, M.; et al. Review on Infrared and Electroluminescence Imaging for PV Field Applications. 2017. Available online: http://www.iea-pvps.org/ (accessed on 22 April 2021).

35. Tsanakas, J.A.; Ha, L.; Buerhop, C. Faults and infrared thermographic diagnosis in operating c-Si photovoltaic modules: A review of research and future challenges. Renew. Sustain. Energy Rev. 2016, 62, 695-709. [CrossRef]

36. Devoto, M.I. Solar Module Characterization via Visual Inspection in the Field, I-V Curve and Thermal-Image Analysis. Rev. Fac. Ing. Univ. Antioquia 2018, 93. Available online: http:/ / repositorio.uchile.cl/handle/2250/159569 (accessed on 22 April 2021). [CrossRef]

37. Olivares, D.; Ferrada, P.; Bijman, J.; Rodríguez, S.; Trigo-González, M.; Marzo, A.; Rabanal-Arabach, J.; Alonso-Montesinos, J.; Batlles, F.J.; Fuentealba, E. Determination of the Soiling Impact on Photovoltaic Modules at the Coastal Area of the Atacama Desert. Energies 2020, 13, 3819. [CrossRef]

38. Ndiaye, A.; Charki, A.; Kobi, A.; Kébé, C.M.; Ndiaye, P.A.; Sambou, V. Degradations of silicon photovoltaic modules: A literature review. Sol. Energy 2013, 96, 140-151. [CrossRef]

39. Sayyah, A.; Horenstein, M.N.; Mazumder, M.K. Energy yield loss caused by dust deposition on photovoltaic panels. Sol. Energy 2014, 107, 576-604. [CrossRef]

40. Rao, R.R.; Mani, M.; Ramamurthy, P.C. An updated review on factors and their inter-linked influences on photovoltaic system performance. Heliyon 2018, 4, e00815. [CrossRef] [PubMed]

41. Guan, Y.; Zhang, H.; Xiao, B.; Zhou, Z.; Yan, X. In-situ investigation of the effect of dust deposition on the performance of polycrystalline silicon photovoltaic modules. Renew. Energy 2017, 101, 1273-1284. [CrossRef]

42. Kuitche, J.; TamizhMani, G. Accelerated Lifetime Testing of Photovoltaic Modules Solar America Board for Codes and Standards. A report of Solar America Board for Codes and Standards (Solar ABC). 2013. Available online: http://www.solarabcs.org/about/ publications/reports/acceleratedtesting/pdfs/SolarABCs-33-2013.pdf (accessed on 22 April 2021). 